\title{
«Yo te seré propicio en Roma» \\ Ignacio de Loyola, la santidad y la construcción del santo
}

$\ll /$ will be favorable to you in Rome»
Ignatius of Loyola, holiness and the construction of the saint

Rogelio GARCÍA MATEO, SI

Pontificia Universidad Gregoriana (Roma)

garcia@unigre.it

\section{Javier BURRIEZA SÁNCHEZ}

Universidad de Valladolid

https://orcid.org/0000-0002-4311-5831

javier.burrieza@uva.es

\begin{abstract}
Starting from the «vision of the Storta» and from that phrase that presides over this spiritual experience of the founder of the Society of Jesus, «l will be favourable to you in Rome», we try to analyse the process of sanctification of Ignatius of Loyola. First, through the hagiography that prepares a climate of perception, above all through the so-called Autobiografia and the «official» Vida written by Pedro de Ribadeneira. Then, with the beginning of the process from the General Congregation of 1593, in the midst of a crisis within the Ignatian Institute itself, accompanied by the intervention of the different monarchies, especially the Catholic and the Christian King, in an international context of European hegemonies of great complexity. Finally, with the beatification in 1609 and the canonization in 1622 (in the company of four other saints who define an ecclesiastical era), the transmission of that holiness, with the creation of a physical image of the new saint, of the feasts celebrated around these decisions and of the stories surrounding them, against the backdrop of the «counter-reform» baroque of the 17 th century.
\end{abstract}

Keywords: Beatifications and canonizations, Ignatius of Loyola, Society of Jesus, Jesuits, holiness, CounterReformation, Catholic Reform.
Resumen: Partiendo de la «visión de la Storta» y de aquella frase que preside esta experiencia espiritual del fundador de la Compañía de Jesús, «yo te seré propicio en Roma», tratamos de analizar el proceso de santificación de Ignacio de Loyola. Primero, a través de la hagiografía que prepara un clima de percepción, sobre todo por la llamada Autobiografia y por la Vida «oficial» escrita por Pedro de Ribadeneira. Después, con el inicio del proceso desde la Congregación General de 1593, en medio de una crisis dentro del propio Instituto ignaciano, acompañado de la intervención de las diferentes Monarquías, especialmente de la Católica y de la del Rey cristianísimo, en un contexto internacional de hegemonías europeas de gran complejidad. Finalmente, con la beatificación en 1609 y la canonización en 1622 (en compañía de otros cuatro santos que definen una época eclesial), se produce la trasmisión de esa santidad, con la creación de una imagen física del nuevo santo, de las fiestas celebradas en torno a estas decisiones y de los relatos en torno a ellas, con el telón de fondo del barroco «contrarreformista» del siglo XVII.

Palabras clave: Beatificaciones y canonizaciones, Ignacio de Loyola, Compañía de Jesús, jesuitas, santidad, Contrarreforma, Reforma Católica. 
La visión de la Storta es una de las escenas más identificadas con Ignacio de Loyola, presente de manera muy temprana en su veneración, en los templos de los jesuitas, en los retablos, pero también en otros soportes como el lienzo. Representaba un pasaje que describía Pedro de Ribadeneyra en su Vida del padre Ignacio:

Aconteció en este camino, que acercándose ya a la ciudad de Roma, entró á hazer oración en un templo desierto y solo, que estava algunas millas lexos de la ciudad. Estando en el mayor ardor de su fervorosa oración, allí fue como trocado su coraçón, y los ojos de su alma fueron con una resplandeciente luz tan esclarecidos, que claramente vio como Dios Padre, bolviéndose a su unigénito hijo que traía la cruz á cuestas, con grandísimo y entrañable amor le encomendava á el, y a sus compañeros: y los entregava en su poderosa diestra, para que en ella tuuiessen todo su patrocinio y amparo. $\mathrm{Y}$ aviéndolos el benignísimo Iesus acogido, se bolvió a Ignacio así como estava con la Cruz, y con un blando y amoroso semblante le dize: «Ego vobis Romae propitius ero». «Yo os seré en Roma propicio y fauorable». Maravillosa fue la consolación y el esfuerço con que quedó animado nuestro Padre desta divina revelación. Acabada su oración, dize a Fabro y á Laynez: hermanos míos, que cosa disponga Dios de nosotros, yo no lo sé, si quiere que muramos en la cruz ó desconyuntados en una rueda ó de otra manera: más de una cosa estoy cierto que de qualquier manera que ello sea, tendremos a Iesu Christo propicio y con esto les cuenta lo que avía visto, para más animarlos y apercibirlos para los trabajos que avían de padecer. De aquí es, que aviendo después nuestro Padre y sus compañeros determinado de instituir y fundar Religión, y tratando entre sí, del nombre que se le avía de poner, para representarla á su Santidad y suplicarle que la confirmasse, el Padre pidió a sus compañeros que le dexassen á el poner el nombre á su voluntad; y aviendoselo concedido todos con grande alegría, dixo el que se avía de llamar la Compañía de Iesús. Y esto porque con aquella maravillosa visión, y con otras muchas y excelentes ilustraciones, avía nuestro Señor impresso en su coraçón este sacratíssimo nombre ${ }^{1}$.

«Yo os seré en Roma propicio y favorable», las palabras que presiden esta «visión de la Storta». Es un punto de partida, el quo vadis ignaciano; una escena vocacional, una experiencia mística en la que el fundador de la Compañía de Jesús cree encontrar la voluntad de Dios para convertirse en un hombre de gobierno, en un fundador, en la ciudad de los Papas. De ahí, la importancia de esta escena para el argumento que nos ocupa: la canonización de Ignacio de Loyola en Roma.

1 Pedro DE RiBadeneYRA, Vida del P. Ignacio de Loyola, fundador de la religión de la Compañía de Iesús; y de los Padres Maestro Diego Laynez y Francisco de Borja, segundo y tercero Prepósito General de la misma Compañia, en las quales se contiene su fundación, progresso y aumento hasta el año de 1572, por Pedro Madrigal, Madrid, 1594, pp. 77-78. 


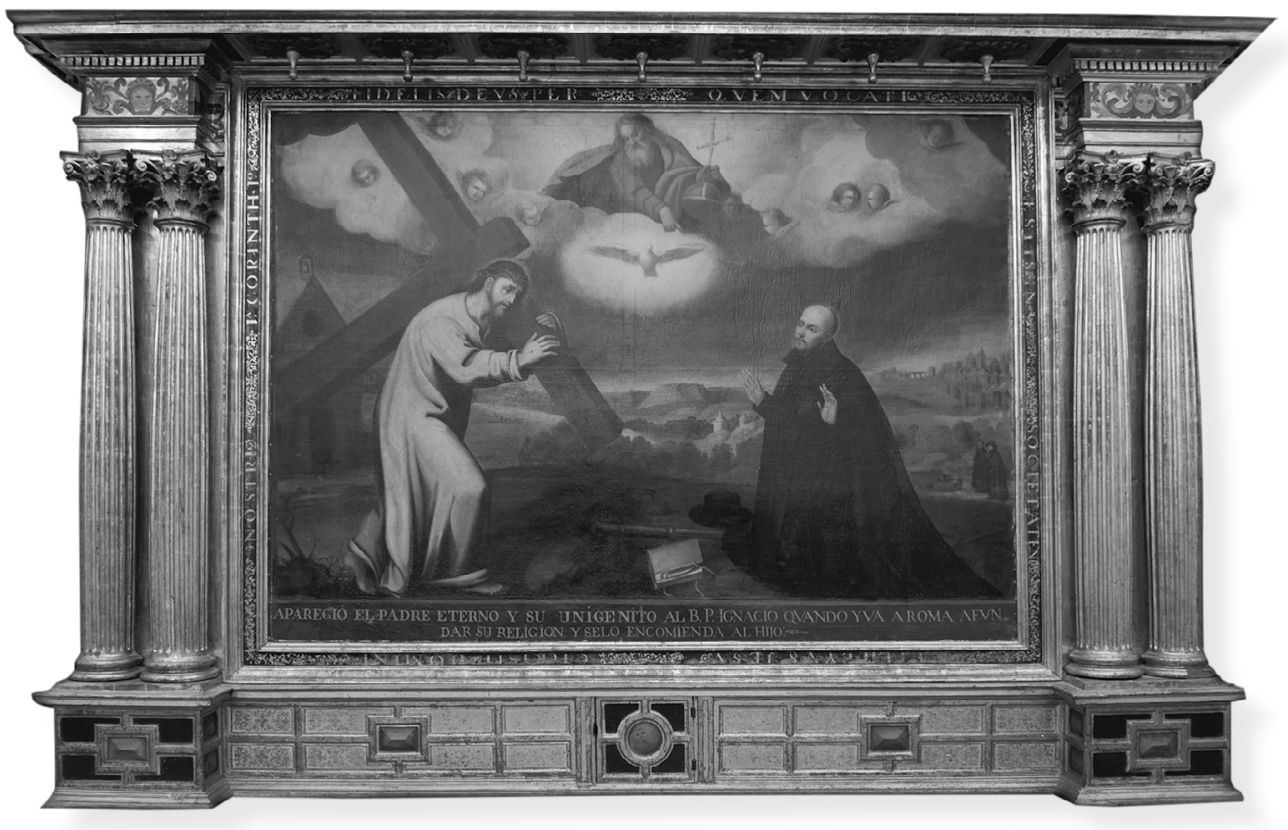

Visión de la Storta, Escuela vallisoletana, principios siglo XVII. Óleo sobre lienzo incrustado en un retablo. Real Colegio de Ingleses de San Albano. Valladolid.

En las palabras que escucha a Cristo con la cruz a cuestas, se produce también su identificación con la Ciudad Eterna y con lo que ella significa en relación con el Papado, cuyo triunfo pleno se produjo en el momento de su canonización en 1622. Palabras providenciales, como se plasman también en su Autobiografía, en su dimensión romana frente al anterior deseo de vivir y morir en Tierra Santa, horizonte que había contagiado a sus compañeros parisinos pero que ellos ni siquiera consiguieron alcanzar. La situación del Mediterráneo lo impedía. Clemente VIII, el Papa del inicio de este proceso de santificación, definió a los jesuitas como el «brazo derecho del papado». Ribadeneyra, en su Tratado sobre la Compañía, destacaba el carácter jesuítico de Roma, Urbe con tantas caras de una misma moneda. En la Ciudad Eterna, a finales del siglo XVI, residían medio millar de religiosos de la Compañía. Se celebraban allí las Congregaciones generales y los procuradores de todas las provincias europeas acudían a ella para informar al prepósito, contando también con sus Congregaciones. La Compañía poseía un gobierno tan centralizado como el de la Iglesia tridentina, una estructura convertida en toda una pauta de «modernidad». Así, el Papa podía conocer o con- 
tar con la información necesaria para disponer de los jesuitas más preparados y adecuados. También sus opositores resaltaban que los jesuitas se creían los «hijos pródigos» de la Santa Sede.

Pero volviendo a nuestra idea inicial, una de las plasmaciones artísticas de esta mencionada «visión» que consideramos más interesante, preside actualmente la sacristía barroca del Real Colegio de Ingleses de San Albano, seminario que estuvo dirigido y administrado hasta 1767 por los jesuitas pero que, probablemente sea una de las representaciones más tempranas «de la Storta» en su relación con la santificación del fundador. En la parte inferior del lienzo aparece una explicación de la escena que estamos describiendo: «Apareció el Padre Eterno y su Unigénito al B. P. Ignacio cuando yva a Roma a fundar su religión y se lo encomendó al Hijo». La consideración del fundador de la Compañía como «Beato Padre» nos sitúa en el intervalo entre su beatificación en 1609 y su canonización en 1622, ambos dos acontecimientos muy celebrados. Si se refiriese a la denominación de «Benerable» todavía estaríamos adelantando más la ejecución de la obra. Se encuentra dentro de un retablo con un pequeño sagrario. Por eso, nos hemos atrevido a pensar que pudo pertenecer a la primitiva iglesia de esta casa, de la cual poseemos escasísimos datos y en la que fue situada en 1600 la Virgen Vulnerata cuando llegó a Valladolid, tras el asalto de los ingleses a Cádiz en 1596. Cuando fue consagrado el templo barroco actual en 1679, con una disposición mucho más ambiciosa, este pequeño retablo pudo trasladarse a su ubicación actual. En el marco que rodeaba el lienzo, ya dentro del retablo podemos leer un versículo de la primera Carta a los corintios: «Fidelis Deus per quem vocati estis in societatis filii eyus Jesu Christi Domini nostri $1^{\text {a }}$ Corinthi $1^{\circ} »-\ll$ Fiel es Dios, el cual os llamó a la comunión con su Hijo Jesucristo nuestro Señor-» $\left(1^{\text {a }} \mathrm{Co}-\right.$ rintios 1,9$)^{2}$.

Estas líneas se escriben en vísperas del quinto centenario de lo que se ha venido conociendo como la «conversión» de Íñigo de Loyola en 1521 y del cuarto centenario de su canonización en 1622 como Ignacio de Loyola. Es menester establecer cómo en su vida se fue gestando el ideal de santidad, pero también como se comunicó la asociada a su persona a través del género hagiográfico, partiendo de elementos muy interesantes que existen para el caso particular del fundador de la Compañía de Jesús.

2 Podemos tomar el ejemplo de esta obra en el Real Colegio de Ingleses de Valladolid: Retablo de la Aparición de Cristo a San Ignacio (Visión de la Storta), en Alejandro Rebollo (coord.), Signa Christi. Símbolos y emblemas de la Pasión, Valladolid, 2015. 


\section{LA AUTOBIOGRAFÍA IGNACIANA Y LA HAGIOGRAFÍA}

La vida y «los saludables ejemplos de los santos, y los milagros que Dios ha obrado por ellos», se daban a conocer a los fieles, según establecía el concilio de Trento, «con el fin de que den gracias a Dios por ellos, y arreglen su vida y costumbres a los ejemplos de los mismos santos; así como para que se esciten á adorar, y amar á Dios, y practicar la piedad» ${ }^{3}$. Permitían, según exponía fray Luis de Granada a Pedro de Ribadeneyra, hacerles presentes entre los lectores. Se refería a san Ignacio de Loyola: «Ay lo tienen siempre bivo sus hijos, para ver en él, no la carne y sangre, sino su espíritu y vida y exemplos de virtudes» ${ }^{4}$. Las páginas de las hagiografías se convertían, en ocasiones, en el medio adecuado para propiciar el ambiente favorable para iniciar un proceso de canonización. De hecho, muchas de ellas eran escritas en los años anteriores. Muchos de aquellos biografiados nunca llegaron a ser reconocidos oficialmente como santos, aunque alcanzarán una «santificación» más popular y rápida. Según apunta Pedro de Ribadeneyra existía una tradición en la historia de la Iglesia de recordar a sus santos y, especialmente, a sus mártires.

Las primeras fuentes de los relatos hagiográficos cristianos son narraciones que describen persecuciones, milagros, tormentos y muertes de los primeros mártires. A partir del siglo III se comienza a celebrar la memoria de hombres y mujeres que, por seguir a Cristo, dan su vida antes que renunciar a su fe; de esa manera el mártir se fue considerando el cristiano más auténtico, el verdadero imitador del Mártir del Calvario. Ya san Ignacio de Antioquía -que tan importante fue para el cambio de nombre de Íñigo López de Loyola-, obispo y mártir del siglo II, se describe en una de sus epístolas como imitador de la pasión de Dios. Las primeras biografías espirituales son las de san Antonio Abad († 357) y de san Martín de Tours († 397), cuyas intenciones son exaltar la santidad de sus protagonistas con el objetivo de despertar en el lector deseos de seguir a Cristo según el testimonio de los santos y recibir la protección de ellos 5 .

3 Concilio de Trento, sesión 25, «De la invocacion, veneracion y reliquias de los Santos, y de las sagradas imágenes». El Sacrosanto y Ecuménico Concilio de Trento, traducido al idioma castellano por D. Ignacio López de Ayala, Barcelona, Imprenta de D, Ramón Martín Indar, 1847, p. 331.

4 RIBADENEYRA, Vida del P. Ignacio de Loyola..., op. cit.; ID., Obras escogidas del Padre Pedro de Rivadeneira de la Compañia de fesús con una noticia de su vida y juicio crítico de sus escritos, edición de Vicente de La Fuente, Biblioteca de Autores Españoles (BAE), Madrid, 1868. Cristóbal LóPEZ, Vida del P. Pedro de Ribadeneyra, religioso de la Compañía de fesús, escrita por el mismo Padre al modo de las confesiones de Sant Agustín, añadida por su compañero que lo fue treinta y seis años, el H. Cristóbal López, Madrid, 1612.

5 Réginald GRÉGOIRE, Manuale di agilogia. Introduzione alla letteratura agiografica, Monastero San Silvestro Abate, Fabriano, 1996; AA.VV., Biographies spiritueles, en DSp, I, 1624-1719. 
Con el reconocimiento de la fe cristiana como religión del Imperio romano, a partir del siglo IV, cesaron las persecuciones y con ello el martirio fue siendo cada vez menos frecuente. Lo que trajo consigo un nuevo modelo de santidad, iniciado por san Antón y san Benito: vivir la radicalidad del Evangelio sin necesidad de encontrar la muerte violenta. Los nuevos imitadores de Cristo van a ser ahora los ascetas y los monjes, en la soledad eremítica de la vida contemplativa. Pero a partir del siglo XIII, con la aparición de las órdenes mendicantes y en el contexto de una sociedad mucho más urbana, que incrementa las actividades artesanales, el comercio y fundación de universidades, surge un ideal de santidad que siente la necesidad de unir a la contemplación la acción apostólica. El ideal evangélico del amor a Dios y al prójimo y los consejos de castidad, pobreza y obediencia, son los medios que los mendicantes, y sus respectivas ramas femeninas, ponen en práctica para vivir la radicalidad del Evangelio, sin necesidad de retirarse en el desierto o ingresar en un monasterio. Esto suponía, a su vez, una formación teológica y pedagógica para poder comunicar las enseñanzas de la fe a los fieles. A la stabilitas loci de los monasterios se une ahora la movilidad apostólica.

De este modo surgen unos iniciadores e iniciadoras que, por su dedicación a la obra comenzada, por su inspiración y especial carisma y por su ejemplar género de vida, fueron llamados Padres y Madres Fundadores, entre otros, san Antonio, san Benito, san Francisco de Asís y santo Domingo de Guzmán. Partiendo de esta tradición, Jerónimo Nadal, uno de los más estrechos colaboradores de san Ignacio, pensó proponerle lo siguiente:

Sabiendo que los santos padres fundadores de algún instituto monástico habían dejado a sus descendientes, a modo de testamento, aquellos avisos que habían de ayudarles para la perfección, buscaba la oportunidad para pedirlo al $\mathrm{P}$. Ignacio... le pedí instantemente que quisiese exponernos el modo como Dios le había dirigido desde el principio de su conversión, a fin de que aquella relación pudiese servirnos a nosotros de testamento y enseñanza paterna.

Es menester adelantar que de manera más breve tanto Jerónimo Nadal como Diego Laínez, de manera más extensa Juan de Polanco, elaboraron las primeras biografías sobre Ignacio de Loyola, que han permanecido inéditas -como recuerda Enrique García Hernán ${ }^{6}$ hasta el siglo XX y que se difundían únicamente por manuscrito, todavía cuando no había fallecido el propio fundador de

6 Enrique García Hernán, Ignacio de Loyola, Taurus - Fundación Juan March, Madrid, 2013, pp. 453-454. Cfr. Joanne Alphonso de POLANCO, Vita Ignatii Loiolae et rerum Societatis Iesu historia, Tomos I-VI (1491-1556), Monumenta Historica Societatis Iesu (MHSI), Matriti, 1894-1898. 
la Compañía: la misión de ésta era la defensa que realizaba de la Iglesia contra sus enemigos, sobre todo personificados en la persona de Lutero. Polanco ya contaba con un Sumario de esta biografía en 1547, con datos semejantes a los que el propio Ignacio de Loyola confesó al padre Cámara seis años más tarde. Los datos referidos a la familia del fundador, tanto en estas páginas como en el llamado Chronicon -una historia de la Compañía que todavía no ha sido publicada en castellano a pesar de los esfuerzos de José García de Castro- los había obtenido Polanco del propio santo, aunque carecían los mismos de una excesiva precisión. Quizás ni siquiera él podía dar cuenta exacta. Nadal, en sus intenciones, se inspiraba en una concepción de la vida monacal. Probablemente, tal punto de partida no le agradó a Ignacio, que se excusó con sus ocupaciones, «diciendo que no podía dedicar su atención y su tiempo a esto». Si él ya no quiso que la nueva orden llevara su nombre, como por costumbre sucedía, tampoco respondía la concepción de la Compañía a remarcar su figura como fundador. Con todo, pasando el tiempo, se produjo en él un cambio de actitud, como cuenta Luis Gonçalves da Camara, que, estando un día comiendo con el padre Ignacio, le dijo:

que muchas veces le habían pedido una cosa Maestro Nadal y otros de la Compañía, y que nunca había determinado en ello; y que, después de haber hablado conmigo, habiéndose recogido en su cámara, había tenido tanta devoción e inclinación a hacello; y -hablando de manera que mostraba haberle dado Dios grande claridad en deber hacello- que se había del todo determinado; y la cosa era declarar cuanto por su ánima hasta agora había pasado; y que tenía también determinado que fuese yo a quien descubriese estas cosas.

Con esta disposición -continúa Da Camara- «el Padre me llamó, y me empezó a decir toda su vida y las travesuras de mancebo clara y distintamente con todas las circunstancias». Es decir, cuando Ignacio se decide a contar su vida no comienza con la conversión, como le pidió Nadal, sino que se trata «de toda su vida», «de cuanto por su ánima hasta agora había pasado», comenzando por su niñez y juventud. Sin embargo, el relato autobiográfico que ha llegado hasta nosotros comienza diciendo: «Hasta los 26 años de edad era hombre dado a las vanidades del mundo» ¿Dónde están esos 26 años que faltan, casi la mitad de su vida?7.

Pedro LetUria, Nuevos datos sobre San Ignacio: la labor de Polanco y Nadal en los orígenes de la biografía ignaciana a la luz de documentos inéditos, Mensajero del Corazón de Jesús, Bilbao, 1925.

7 Luis FERNÁNDEZ MARTÍN, Peripecia histórica de la «autobiografía» ignaciana, en José Luis ORELLA (ed.), El Pueblo Vasco en el Renacimiento (1421-1521). Actas del Simposio celebrado en la Universidad de Deusto (San Sebastián) con motivo del V. Centenario del nacimiento de Ignacio de Loyola (1-5 octubre 1990), Mensajero - Universidad de Deusto, Bilbao, 1991, pp. 161-190. 
De lo poco que el relato autobiográfico ignaciano servía para los objetivos hagiográficos que facilitarían seguramente una pronta canonización, lo documenta el hecho, hoy incomprensible, de que no solo no se imprimió, sino que fueron retiradas las copias manuscritas circulantes por orden del entonces prepósito general Francisco de Borja (1565-1572), y en su lugar se puso la Vita Ignatii (1571) de Pedro Ribadeneyra ${ }^{8}$. La orden de Borja decía: «Que se recoja lo que escribió el P. Luis Gonçalves... y no permitan que se lea... pues siendo cosa imperfecta, no conviene que estorbe y disminuya la fe de lo que más cumplidamente se escribe» ${ }^{9}$. Incluso por sus contemporáneos, y especialmente dentro de la Compañía, a Ribadeneyra se lo ha considerado el «padre de la hagiografía moderna». No solamente disponía de una obra más genérica y monumental como fue el Flos sanctorum (1599) sino también las que escribió y publicó sobre los tres primeros prepósitos generales de la Compañía: Ignacio de Loyola, Diego de Laínez y Francisco de Borja. Sobre el primero, la edición fue en latín para después salir en castellano, desde la Corte y en 1583, dedicada al arzobispo de Toledo, Gaspar de Quiroga, cuyo testimonio sobre el fundador de la Compañía fue temprano ${ }^{10}$.

En efecto, con el relato autobiográfico de Ignacio de Loyola difícilmente se hubiese podido presentar la vida de un santo tal y como entonces se entendía entonces. Ni grandes milagros y prodigios, ni ascetismo moralizante, sino confesión, que edifica por la realidad de los hechos, netos y desnudos de mistificaciones. Parece como si él respondiese haciendo eso que él tanto practicaba -el examenante toda la Compañía, para que ella se edifique con la totalidad de su vida, no

8 Ribadeneyra, en Diccionario Histórico de la Compañia de Fesús. Histórico-Temático, vol. IV, Institutum Historicum Societatis Iesu - Universidad Pontificia de Comillas, Roma-Madrid, 2001, pp. 3345 y ss.

9 Monumenta Historica Societatis Iesu (en adelante, MHSI), Epistolae P. Hieronymii Nadal, t. III, p. 490, además pp. 365, 402, 505, 540 .

10 «Él escriuió el libro de la vida del P. Ignacio, que anda impressa con nombre del P. Pedro de Ribadeneyra, en latín y en castellano, la qual escribió por orden del P. Francisco de Borja, general de la Compañía, que se la mandó escriuir por juzgar que tenía la noticia que era menester para escriuirla [...] dixo que no ay cosa en el dicho libro de la vida del P. Ignacio que él escriuió, que él entienda que es falsa; a lo menos que no se acuerda que aya scripto cosa falsa sabiendo que lo es, antes cree y tiene por cierto que todo lo que dize en el dicho libro, moralmente hablando, es verdadero, por que puso gran diligencia y cuidado en guardar entera verdad y en escriuir lo que vió y oyó del mismo P. Ignacio, o lo que él contó de sí, o otras personas graues contaron dél, o él pudo sacar de originales y papeles muy ciertos y aueriguados», en MHSI, Monumenta Ignatiana ex autographis vel ex antiquioribus exemplis collecta. Series Quarta. Scripta de Sancto Ignatio de Loyola Societatis Fesu Fundatore. Tomus Secundus, Matriti, 1918, p. 153 (en adelante MHSI, Monumenta Ignatiana) 
solamente con los grandes momentos, sino también en las horas, en los meses y años en que Dios, la gracia, la fe, se sienten como realidades muy lejanas.

Fue en 1731 cuando se publicó por primera vez, aunque en versión latina, el texto autobiográfico, en la colección de los bolandistas, y en 1904 el texto de una de las siete distintas copias, la $N$, que han llegado hasta hoy, y que se encuentran en el archivo de la Curia generalicia en Roma. El texto original redactado por Gonçalves da Camara, parte en español y parte en italiano, no ha llegado hasta nosotros. Una vez publicada dicha copia en la colección Monumenta Historica Societatis Iesu, ya se pudo hacer una edición manual de ella, junto a otros escritos ignacianos, con el título Autobiografía. Su texto fue publicado en 1947 por la Biblioteca de Autores Cristianos ${ }^{11}$.

Aunque Ribadeneyra utilizó, para su vida de san Ignacio, el texto de Da Camara y no se atiene a la tipología medieval de la legenda áurea (Flos sanctorum), emplea un método más histórico, según modelos del Renacimiento; sigue con las intenciones hagiográficas de utilizar los hechos en sentido apologético o edificante, exaltando la vida ejemplar y grandes virtudes del fundador; añade comentarios piadosos y construcciones históricas de la época, interpretando los hechos según el esquema contrarreformista que ve en Ignacio el Antilutero por antonomasia:

Cuando [surgió] del abismo Martín Lutero como un monstruo infernal, acompañado de su escuadrón de abominables y diabólicos ministros..., al mismo tiempo envió Dios nuestro Señor de socorro otro varón y capitán de su Iglesia, en todo contrario a Lutero, para que con su espíritu invencible y armas poderosas y divinas valiosamente le resistiese y pelease las batallas del Señor ${ }^{12}$.

Pero Ignacio no habla en ninguno de los escritos, que han llegado hasta nosotros, de Lutero, sino solo de «los luteranos» ${ }^{13}$. Si se tiene en cuenta que las interpretaciones contrarreformistas y hagiográficas, que iniciaron algunos

11 San Ignacio de Loyola, Obras completas de... 1, Autobiografía, Diario espiritual, introducciones y comentarios de Victoriano Larrañaga, Editorial Católica, Madrid, 1947. Existe una edición más reciente: Autobiografía y diario espiritual, introducción de Luis $M^{a}$ Mendizabal, transcripción y notas de Ignacio Iparraguirre, Candido de Dalmases y Manuel Ruiz Jurado, Biblioteca de Autores Cristianos, Madrid, 1992.

12 MHSI, Fontes narrativi, IV, pp. 339 y ss.

13 Rogelio GARCÍA MATEO, Loyola y el luteranismo ¿Contrarreformista o reformista?, en Estudios Eclesiásticos, 82 (2007), pp. 309-338; Fermín LABARGA, La recepción de Lutero en España, en Gert MELVILLE y Josep Ignasi SARANYANA ClOSA (eds.), Lutero 500 anni dopo. Una rilettura della Riforma luterana nel suo contesto storico ed ecclesiale, Libreria Editrice Vaticana, Città del Vaticano, 2019, pp. 239-264. 
de los primeros jesuitas -junto a Ribadeneyra, Borja, Canisio, Nadal-, son las que han marcado la figura y la obra ignacianas, entonces habrá que decir que ha sido necesario recorrer un camino prolongado para alcanzar una evaluación histórica objetiva. Desde el postconcilio, bajo el generalato de Pedro Arrupe y siguiendo el programa del Vaticano II de vuelta a las fuentes de la fe, los estudios históricos y sistemáticos ignacianos se han renovado considerablemente, sobre todo a partir de 1991, quinto centenario de su nacimiento ${ }^{14}$. García Hernán ponía de manifiesto las llamadas «desfiguraciones de su verdadero rostro» que realizó Ribadeneyra, muy crítico -según este historiador- con todo aquello que no hubiese sido escrito por él. Fue el autor que se encargó muy mucho en fijar una «biografía oficial de Ignacio». Consideraba García Hernán que cuando la Congregación General, en 1593, decidió poner en marcha -como veremos- los procesos informativos que habrían de culminar en el proceso de beatificación, fue cuando se inició el tipo de «biografía edificante». La canonización estaba culminada treinta años después. A este periodo pertenecía la mencionada obra de Ribadeneyra, así como las de Maffei (Roma, 1585), Lancicio (Roma, 1609), Orlandini (Roma, 1619), Bartoli (Roma, 1650, ya después de la canonización y reeditado en los siglos XVIII y XIX), sin olvidar al muy censurado Juan Eusebio Nieremberg (en 1631), en un tiempo muy cercano a la canonización o el también jesuita madrileño Francisco García (en la Corte, en 1685). Debemos considerar que la base de todas las biografías realizadas en el siglo XVII fueron las primeras y mencionadas de Ribadeneyra y Maffei. Después de la publicación de éstas, la documentación ignaciana empezó a estar vedada ${ }^{15}$. Daniello Bartoli será el primero que retomó nuevos datos. A partir de la primera mencionada edición de la Autobiografía por los bolandistas, se escribía un Compendio de la Vida de Ignacio de Loyola que aún se encuentra inédita mientras que el cardenal austracista Álvaro de Cienfuegos preparaba un amplísimo volumen en el siglo XVIII con documentación de los procesos de canonización.

No puede quedar duda: la obra de Ribadeneyra es encomiable, aunque tenga los defectos mencionados, y siguiendo la intención de Nadal y del superior general Borja, despacha en dos páginas y media los aproximadamente treinta años antes de la «conversión», esto es, casi la mitad de su vida. Sin embargo, tematiza en unas trescientas cincuenta páginas, con detalle y orden, las diversas etapas de la vida del Fundador de la Compañía desde la conversión hasta su

14 Quintín ALDEA, Ignacio de Loyola en la gran crisis del siglo ХVI, Mensajero, Madrid, 1992.

15 García Hernán, Ignacio de Loyola, op. cit., p. 455. 
muerte; por ello su Vita Ignatii fue y seguirá siendo, con las debidas salvedades, un referente importante para conocer al santo de Loyola. García Hernán advierte que hasta la Historia de la Compañia de fesús en la Asistencia de España (en su primero tomo en 1902), sobre las biografías redactadas por Ribadeneyra y Maffei no se había aplicado ningún criterio científico ${ }^{16}$. Considera que lo escrito por Antonio Astrain no despertó entusiasmos, cuando ya se habían publicado recopilaciones documentales en el Monumenta Historica Societatis Iesu. Sin embargo, los tomos de este historiador contemporáneo resultan una referencia inevitable.

\section{EL PROCESO DE SANTIFICACIÓN DE IGNACIO DE LOYOLA}

Además de las consideraciones teológicas que existiesen sobre el santo, en este tiempo de cambio debido al Humanismo y la llegada de las Reformas -con la luterana-, era necesario que la Iglesia llevase a cabo una reglamentación para llegar hasta un reconocimiento de la santidad. En el tiempo de aplicación de Trento, Sixto V creaba la Congregación de Ritos, dentro del reforzamiento del poder centralizado de la Iglesia católica, es decir, de la Curia y de los «ministerios» que la configuraban. Los procesos de canonización pasaban a ser competencia de esta Congregación, aunque la decisión final y pronunciamiento se lo reservaba el Papa. Por otra parte, desde Trento, se va a llevar a cabo la institucionalización de una fase transitoria hacia la santidad, más propia de una canonización localizada. Será la beatificación. Previa a ella, se reglamentaba la otra fase, nacida desde los ámbitos más domésticos aún si cabe: la de los siervos de Dios o venerables. Urbano VIII, adelantado el siglo XVII, llevó a cabo una reglamentación de los procesos de beatificación y canonización, aunque la de Ignacio de Loyola se produjo con Gregorio XV, el nombre adoptado por el cardenal Alejandro Ludovisi, antiguo alumno de los jesuitas. Una nueva normativa en la que será necesario aportar una «base» informativa muy amplia que fuese capaz de aportar numerosos datos biográficos sobre el candidato. Una documentación que, además, se encontraba apoyada por las voces de la autoridad. Y todo ello con una posterioridad amplia desde su fallecimiento. Esta primera fase se la conoció como la de los Procesos Informativos.

16 Ibid., p. 457. 
Estanislao de Kostka fue el primer miembro de la Compañía que, en 1602 por breve de Clemente VIII, recibió el título de «beato» para el reino de Polonia, «donde començaron desde luego a venerarle, invocándole y offreciéndole votos» ${ }^{17}$. Por igual procedimiento, en agosto de 1670, el papa Clemente X extendió el culto de Kostka a todo el mundo católico. Como ocurría en estos casos, el rey Federico Augusto de Polonia y el duque elector de Sajonia pidieron la canonización de este jesuita polaco, que llegó finalmente en 1726. Por su parte, Clemente VIII fue el que autorizó en 1605 a que se venerase a Luis Gonzaga, fallecido en junio de 1591, oficialmente como beato, imprimiéndose su Vida con tal consideración. Una decisión que fue muy bien recibida por la aristocracia italiana, civil y eclesiástica, pues el joven jesuita se encontraba emparentado con ella. Por eso, las fiestas que entonces se celebraron no fueron únicamente una exaltación de la Compañía de Jesús sino más bien de las familias a las que pertenecían. En 1607, el Papa pidió a la Sagrada Congregación de Ritos que examinase «la pureza de su fe, la santidad de su vida, de la fama de sus milagros y de la piedad con que el pueblo le veneraba». La Congregación comisionó a jueces en Roma, Mantua, Parma y Castellón, con examen de los testigos, con un proceso que fue remitido a la propia Congregación. Las sobrinas de Luis Gonzaga, además, fundaron en Castellón un colegio de la Compañía donde se recibió la cabeza del beato, junto con los cuerpos de otros santos procedentes del cementerio de Santa Priscila de Roma. Un culto que se extendió en España por vía de los embajadores. En la fiesta que por su iniciativa se celebró en la iglesia de la Compañía en Madrid, se contó ya con una imagen del beato Luis Gonzaga. Fue una gran ceremonia de Corte con asistencia de Felipe III y Margarita de Austria junto al cardenal Toledo o el nuncio del Papa. Desde noviembre de 1612, se inició la carrera de concesiones pontificias para la consideración y veneración como beato. Nos referimos a la misa y oficios propios para toda la Compañía, para los estados de los príncipes de Gonzaga, para el Colegio Romano donde se encontraba enterrado, para los templos de los colegios de Roma. Cuatro años después, Gregorio XV permitía que los jesuitas del mundo pudiesen celebrar esta misa, así como cualquier sacerdote que lo hiciese en una iglesia propia de la Compañía. Habrá que esperar a diciembre de 1726 para la canonización de ambos, el último día del año.

17 Fue el primero de la Compañía, a quien concedió culto la Silla Apostólica, en Bartolomé de ALCÁZAR, Chrono-Historia de la Compañia de Jesvs en la Provincia de Toledo y elogio de svs varones ilustres, fundadores, bienhechores, fautores e hijos espirituales, escrita por..., por Juan Garcia Infançon, Madrid, 1710, t. II, p. 188. 
Por eso cabe preguntarse, ¿por qué los jesuitas no promocionaron previamente la santidad de su fundador? Dejó bien claro Tachi-Venturi ${ }^{18}$ que el deseo de ver a Ignacio de Loyola, en los altares, fue inmmediato a su fallecimiento en julio de $1556^{19}$. El constante secretario que fue Juan de Polanco dirigió importantes cartas a lo que se llamaba la «gente grave», aquellos ilustres que desde distintos puntos habían favorecido a la Compañía o podían ser un punto de apoyo para la difusión de la fama de santidad de su fundador. De esta manera, escribió a Bruselas al conde de Feria, al Rey de Romanos o al cardenal Alejandro de Farnesio. No serán los únicos, como se demuestra en sucesivos días de aquel verano de 1556, cuando se solicitaba el apoyo de Margarita de Austria, duquesa de Parma e hija del emperador.

No fue hasta la V Congregación General de 1593-1594 cuando la Compañía tomó la decisión de abrir el proceso ${ }^{20}$. La anterior, celebrada en 1582, en la que se perfiló definitivamente la fisonomía de la Compañía, había elegido Prepósito General el napolitano Claudio Aquaviva, de tan solo treinta y ocho años. En 1573, en la III Congregación General, celebrada en Roma tras la muerte de Borja, los padres que habían participado en ella, comían escuchando la lectura «edificante» de la Vita Ignatii Loiolae escrita por Ribadeneyra, impresa en Nápoles el año anterior en latín. Empezaron a llegar los testimonios, dirigidos a quién había puesto ya por escrito su Vida. Fue el caso de las «Letras testimoniales de la vida y

18 Pietro TACCHI-VENTURI, Storia della Compagnia di Gesù in Italia narrata col sussidio di fonti inediti dal P..., I, Roma-Milano, 1910. Acta Sanctorum... Julii. Tomus Septimus, apud Victorem Palmé Bibliopolam, Pariis et Romae, 1868, pp. 420-605.

19 «En esta casa y collegios [de Roma], aunque no puede dexarse de sentir la amorosa presencia de tal Padre, de que nos hallamos priuados, es el sentimiento sin dolor, las lágrimas con deuoçión, y el hallarle menos, con aumento de sperança y alegría spiritual. Parézenos de parte dél que ya era tiempo que sus tan continuos trabajos llegasen al uerdadero reposo: sus enfermedades a la uerdadera salud; sus lágrimas y continuo padecer a la bienauenturança y felicidad perpetua. De parte nuestra no solamente no pensamos hauerle perdido, pero aora más que nunca speramos ayudarnos de su ardentíssima charidad, y que por interçessión suya, la diuina misericordia aya de acrecentar el spíritu y número y funciones de nuestra Compañía para el bien vniversal de su yglesia», en Carta de fuan de Polanco a Pedro de Ribadeneyra, Roma 6 agosto 1556, en MHSI, Monumenta Ignatiana, t. II, Madrid, 1918, p. 19.

$20 \ll$ La congregación [general], para proceder más madura y acertadamente, quiso primero saber el paño que teníamos y hizo ver algunos letrados y curiales de Roma ciertos papeles que yo [Ribadeneyra] auía embiado (aunque eran pocos) y otras cosas que allá abían juntado, para que dixesen su parecer; y todos, después de auerlos visto, dixeron que muy seguramente podía la congregación tratar deste negocio, porque tenía paño bastante y sobrado para lo que la Compañía pretendía. Con esto, la congregación general hizo vn decreto en que encargó al P. General, que de su parte y de toda la congregación suplicase a su santidad que nos hiziese esta merced», en Carta de Pedro de Ribadeneyra a los padres de la Congregación Provincial, Madrid, 5 abril 1597, en ibid., pp. 402-403. 
persona del Padre Ignacio de Loyola, fundador de la Compañía de Jesús», donde encontramos el testimonio del cardenal Gaspar de Quiroga. ¿Cuál había sido el fruto de este fundador? El cardenal lo exponía en su carta:

El ejemplo de su santa vida y con su saludable doctrina y con la institución y propagación y gobierno de su misma religión que en tan pocos años se ha estendido por todo el mundo, se ha hecho grandísimo fruto así en resistir a los herejes como en alumbrar a los gentiles, y reformar las vidas de los cathólicos y fieles, como es notorio. Por tanto habiendo nos conocido y conversado familiarmente y tratado muchos negocios en Roma con el dicho bienaventurado Padre (lo qual entre otras reconocemos por muy gran merced de Dios) y por esto teniendo noticia de su santa vida y persona, para que el Señor sea más glorificado, en este su siervo, declaramos por estas nuestras letras que es verdad que le conocimos y comunicamos muchas y diversas veces y tuvimos estrecha amistad con el dicho devoto Padre Ignacio de Loyola [...] le tuvimos siempre por hombre verdaderamente humilde, manso, paciente, caritativo, zeloso de la gloria de Dios y del bien de sus prójimos, menospreciador del mundo, prudente y magnánimo, y entre todas las mudanzas de tiempos, blandos y ásperos, prósperos y adversos ${ }^{21}$.

Será entre julio y septiembre de 1593 cuando se van a desarrollar el proceso en Burgos, Loyola, Toledo, Madrid, Alcalá de Henares, Azpeitia, Barcelona, Manresa o Montserrat ${ }^{22}$. Ese mismo verano, el procurador general de la Compañía de Jesús en la Corte madrileña, Gaspar de Pedrosa, interrogaba «cerca de la vida, virtud y sanctidad del P. Ignatio de Loyola» a Pedro de Ribadeneyra:

Le trató muy familiarmente algunos años, porque, siendo de edad de catorce años aun no cumplidos, estando en Roma, nuestro Señor fue seruido que entrasse en la casa y Compañía del mismo Padre el año de 1540 [...] Y después biuió el dicho P. Ignacio casi diez y seis años, de los quales el dicho testigo le trató en diferentes tiempos, como ocho años, muy últimamente, porque durmió en su aposento, y le seruía en él, ayudábale a dezir missa y a escriuir, acompañáuale fuera de casa, y hizo un camino con él; trató muchos y graues negocios con él, siendo ya hombre, y siendo moço se los vió tratar, y finalmente el año de 1555 fué embiado por el mismo P. Ignacio a Flandes al rey cathólico, don Phelipe, a negocios graues y a declarar a los de la Compañía que estauan en aquellos estados las Constituciones que auía scripto el dicho P. Ignacio para el buen gouierno della ${ }^{23}$.

21 Testimonioum Cardinalis Gasparis de Quiroga de Sanctitate Ignatii, Matriti 6 julii 1593, en ibid., pp. 110-111.

22 Ibid., pp. 112-126, 128-149, 167-259, 262-351, 352-381, 381-386.

23 Patris Petri de Ribadeneyra. Testimonium de Ignatii Sanctitate, Matriti 31 julii - 5 august 1595, en ibid., pp. 152-153.

\section{- 000}


Indicaba Ribadeneyra que estos procesos se habían realizado por si alguno de los testigos moría, disponiendo en su validación de la autoridad del nuncio. También podían servir para acelerar el proceso en el caso de que nuevas exigencias llegasen desde la comisión pontificia y se tuviesen que tomar declaraciones en un tiempo más reducido ${ }^{24}$. En esos mismos meses del verano de 1595, en una carta desde Madrid de Ribadeneyra al prepósito general Claudio Aquaviva, le exponía que cuatro cosas había que tener presente: la necesidad de que hubiese en Roma un padre dedicado a este negocio, ofreciéndose el propio escritor a ayudarlo en aquellas cuestiones, en las «cosas antiguas de la Compañía» que tendría que averiguar; un segundo «postulador»-él no utiliza esta palabra-para España «en este negocio que tanto nos importa», debiendo contar con la ayuda de los provinciales; la necesidad de escribir a todos los provinciales europeos para contar con información inmediata acerca de la fama de santidad o del suceso de milagros y disponer, también, del apoyo de los príncipes católicos. No era suficiente la presencia, parecía que inmediata, de Felipe II y de su hermana la emperatriz María de Austria -que ya vivía en Madrid, retirada, en su fundación de las Descalzas Reales-. Era «menester juntar la intercessión de los otros príncipes de la christiandad». Y para ello consideraba fundamentales al emperador de Alemania, Rodolfo II (hijo de la anterior), al rey de Polonia, al príncipe de Transilvania, y a los duques de Baviera y de Saboya. Así se lo exponía Ribadeneyra a Aquaviva «para que lo guíe y modere con su prudencia y espíritu» ${ }^{25}$. En abril de 1597, se dirigió este escritor a los padres de la Congregación Provincial haciendo informe del estado en que se encontraba el «negocio de la canonización» en los últimos cuatros años desde que se inició. Advertía que los gastos eran numerosos, «muchos i forçosos», por lo que sería menester pedir limosna, y no solo en Italia, debiendo ser necesaria una lista de personas acomodadas a las que recurrir ${ }^{26}$.

24 Carta de Pedro de Ribadeneyra a los padres de la Congregación Provincial, Madrid 5 abril 1597, en ibid., p. 405.

25 Carta de Pedro de Ribadeneyra a Claudio Aquaviva, Madrid 12 agosto 1595, en ibid., pp. 259-261.

26 «Lo que a mí se me ofrece, es que VR deuría de azer vna lista de las personas poderosas i deuotas que se entiende podrán i querrán dar limosna para esta obra i luego considerar qué Padres o personas de la Compañía tienen amistad o entrada, o serán a propósito para con ellas, para representarles esta necessidad con el buen término i religioso que conuiene, i repartir esta demanda a las personas que VR juzgare, para que cada vno la proponga a las personas que VR señalare en cada colegio i ciudad, i azer vna memoria de lo que cada persona fuere dando o prometiendo, i vn depositario que lo tenga i guarde asta que sea menester», en Carta de Pedro de Ribadeneyra al padre Hernando Ponce, Madrid, mes de noviembre 1605, en ibid., p. 513. 
Esther Jiménez piensa que el proceso de canonización de Ignacio de Loyola, y del grupo de nuevos santos que protagonizaron aquella ceremonia de $1622^{27}$, se encuentra contextualizado dentro de las controversias sobre el modelo de santidad que se produjeron entre cardenales de la curia vaticana, sobre todo entre dos grupos. El primero estaría encabezado por el cardenal Giulio Antonio Santori, gran inquisidor y apoyado desde la Monarquía católica de Felipe II. El segundo por el propio cardenal Aldobrandini, que habría de ser elegido como papa Clemente VIII y que optó políticamente por el perdón hacia un antiguo príncipe calvinista que se habría de convertir en monarca católico de Francia, Enrique IV. Estos segundos, desde la defensa de una espiritualidad reformista, encontraban sus modelos de actuación en los que habrían de ser los futuros santos del barroco católico: Felipe Neri, Teresa de Jesús, Carlos Borromeo, Ignacio de Loyola o Francisco Javier, acompañados de los frutos de sus obras, los oratorianos, los jesuitas y los carmelitas descalzos junto con los frailes dominicos de Santa María sopra Minerva. Cada uno de esos modelos representaba al sacerdote, a la monja, al cardenal, al fundador o al misionero reformista. Sin embargo, en el caso de Ignacio de Loyola, ¿en qué etapa de su vida había que fijarse para que fuese impulsada su santificación?

Podían optar, como indica José Ignacio Tellechea ${ }^{28}$, con el que camina «solo y a pie», que tiene que salir de Castilla con sospechas de alumbradismo o más bien por el Ignacio de Loyola que conoce a sus compañeros en París, que experimenta el modus parisiensis y que pretende, con aquellos primeros «amigos en el Señor» peregrinar a Tierra Santa; al no conseguirlo, en conjunto, se ponían a disposición de lo que el papa Paulo III quisiera disponer de ellos. Es el Ignacio de Loyola con el que hemos comenzado de manera muy plástica, el de la «visión de la Storta». Después, este Instituto, aprobado en 1540, había sido identificado con la Monarquía de España -sobre todo en los días de Paulo IV-. Gregorio XIII había impedido que el que había sido secretario de Ignacio de Loyola, de Diego Laínez y de Francisco de Borja -Juan de Polanco-, fuese elegido por la Congregación General su cuarto prepósito. Eso, había despertado a los llamados «memorialistas», apoyados en cierta manera por Felipe II, dentro de un conflicto en la Compañía de Jesús española que ha sido denominado, por Ricardo García

27 Esther JimÉNEZ PABLO, La canonización de Ignacio de Loyola (1622): lucha de intereses entre Roma, Madrid y París, en Chronica Nova, 42 (2016), pp. 79-102. Cfr. ID., La forja de una identidad. Las Compañia de fesús (1540-1640), ediciones Polifemo, Madrid, 2014.

28 José Ignacio Tellechea IdÍGORAS, Ignacio de Loyola, solo y a pie, Sígueme, Salamanca, 1997. Se trata de una de las biografías contemporáneas clásica de Ignacio de Loyola. 
Cárcel, como el «nacionaljesuitismo» ${ }^{29}$. La identificación entre la Compañía y la Monarquía de Felipe II se fue diluyendo y complicando.

Felipe II, que deseó tener un superior español al frente del Instituto ignaciano -como lo habían sido el propio fundador, Laínez y Borja- se encontró con Aquaviva en el periodo más prolongado de gobierno, hasta 1615. Los españoles fueron apartados de la vanguardia de gobierno de la misma, en un tiempo de universalización de la Compañía -aunque los jesuitas habían llegado a América de manera definitiva con Borja-. La línea reformista que defendía el grupo curial mencionado fue la que se impuso en la Congregación de 1593-1594. Eso sí, un español, más joven que los primeros compañeros cofundadores pero próximo al fundador, Pedro de Ribadeneyra -aquel que había justificado la derrota de la Monarquía católica con la «Armada Invencible»- consideró que aquel era el momento para que la Compañía solicitase a Clemente VIII la canonización de Ignacio de Loyola. No era éste un mártir como los de Japón o un defendor de la fe frente a un anglicanismo imperante como sucedía con Edmund Campion, también jesuita. El retrato del fundador no debía responder al caminante sospechoso que pasó por Castilla sino al prepósito general de una orden, una piedra angular, del Reformismo católico.

Felipe II se dirigió a su embajador en Roma -el duque de Sessa- para saber cómo debía actuar en este asunto ${ }^{30}$. Según narra Ribadeneyra éste ya le había en-

29 Ricardo GARCÍA CÁRCEL, La crisis de la Compañía de fesús en los últimos años del reinado de Felipe II (1585-1598), en La Monarquía de Felipe II a debate, Sociedad Estatal Conmemoraciones, Madrid, 2000, pp. 383-404.

30 «Los de la Compañía de Jesús muestran mucho desseo de la canonización del Padre Ignacio su fundador, como lo hauréys entendido; y a mi me han pedido con instancia interceda con su santidad para que se sirua de ponerlo en execución. La obra sería, cierto, buena; pero antes de interponerme en ello, he querido informarme de vos cómo se recibe allá esta pretensión destos Padres; y assí me lo auisaréys con toda breuedad y secreto, para que conforme a la disposición que ay huuiere de tratar desta materia, me resuelua en lo que más conuiniere», en Carta de Felipe II al duque de Sessa, San Lorenzo de El Escorial, 17 octubre 1593; «Vuesta carta de 2 de hebrero [de 1594] sobre lo de la canonización del Padre Ignacio se recebió con el papel de sus milagros que los Padres de la Compañía presentaron ay, que he holgado de verle; y pues dezís que se recibe bien esta plática, he resuelto de escriuir a su Santidad [Clemente VIII], como os parezce, supplicándole tenga por bien de canonizar este Santo, como lo veréis por la copia que se os envía juntamente con la misma carta. Vos la daréis a su Santidad, a su tiempo, quando los mismos de la Compañía os lo auisaren, añadiendo las razones que os parezieren a propósito para mouer a su Santidad a esta obra de que se siguirá tanta gloria a su dichosa memoria; y le pidiréys que mande despachar los breves en la forma que se suele, para que se dé principio a ello; y os entenderéis en esto con el cardenal Toledo y con los demás de la Compañía; y haréis para encaminarlo todos los buenos officios que conuinieren; y me avisaréys a menudo de lo que se fuere haciendo», Carta de Felipe II al duque de Sessa, San Lorenzo de El Escorial, 6 agosto 1594. En este último día, Felipe II se dirigía al papa Clemente VIII. Cfr. MHSI, Monumenta Ignatiana, t. II, pp. 16-127. 
viado algunos papeles que los curiales habían visto en la Ciudad Eterna. Mandó el Rey que el asunto fuese tratado en el Consejo de Estado, donde se encontraba el entonces archiduque cardenal Alberto de Austria -su sobrino y futuro yerno fuera ya del estado eclesiástico- o el cardenal Quiroga, estableciendo el monarca que el «negocio» debía ser favorecido. Felipe II se dirigió a Clemente VIII, con nuevas epístolas recomendatorias de su hermana, la emperatriz María de Austria. Recibido de manos del embajador muchos de estos documentos, el pontífice se los entregó al cardenal jesuita Francisco de Toledo para su estudio. Según apunta Ribadeneyra, este último le indicó que no eran necesarios los milagros para la canonización si constaba por otra parte que el siervo era santo; que en este caso sobraban los testimonios, también de los milagros en vida y después de muerto; pero si además se dudaba, «el mayor milagro de todos era el auerle tomado Dios para fundador y padre de una religión como la Compañía y haverla extendido por el mundo con tantos y tan grandes y milagrosos effectos como se ha visto, para gloria de Dios y beneficio de toda la Iglesia $\gg^{31}$. La promoción de este jesuita cordobés a la púrpura cardenalicia había sido más que complicada, ocasionando problemas notables en su convivencia con la Compañía, con sus superiores y con su prepósito general. Para procurarse el apoyo de Felipe II, Aquaviva se quiso valer de Ribadeneyra y llegar a través del secretario Juan Idiáquez, miembro del Consejo de Estado. Después de que Clemente VIII crease cardenal a Francisco de Toledo en 1592, un grupo de jesuitas descontentos -entre los que podía estar José de Acosta- procuraron que el nuevo purpurado presidiese la mencionada Congregación General de 1593. Toledo también estuvo implicado en el asunto de la «conversión» del monarca francés. Revitalizador de la escolástica en este siglo XVI, murió en septiembre de 1596, poco tiempo después de haber sido consultado por su protector Clemente VIII acerca del proceso de su fundador. El pontífice escribió el epitafio de su tumba ${ }^{32}$.

31 Referencia de lo que había indicado el cardenal Francisco de Toledo al papa Clemente, en la carta que Pedro de Ribadeneyra dirige a los padres de la Congregación Provincial (Madrid 5 abril 1597), en ibid., pp. 403-404.

32 Padre Francisco de Toledo, en Juan Eusebio NiEREMBERG, Firmamento religioso de luzidos astros en algunos claros varones de la Compañia de Jesús, Madrid, 1644, pp. 608-613; Francisco CERECEDA, En el cuarto centenario del nacimiento del P. Francisco de Toledo, en Estudios Eclesiásticos, 13 (1934), pp. 90108; Rafael SÁNCHEZ DE LAMADRID, El tratado del Cardenal Toledo sobre la canonización de los santos, en Archivo Teológico Granadino, 3 (1940), pp. 171-210; P. SUÑER, Toledo, Francisco de, SI, en Quintín Aldea, Tomás MartíneZ y J. Vives Gatell, Diccionario de Historia de la Iglesia española, Instituto Enrique Flórez, CSIC, Madrid, 1972-1987, vol. IV, pp. 2572-2574; Ángel SANTOS HERNÁNDEZ, fesuitas y obispados. La Compañia de fesús y las dignidades eclesiásticas, Universidad Pontificia de Comillas, Madrid, 1998, vol. 1, pp. 106-124; Javier BURRIEZA SÁNCHEZ, Toledo, Francisco de, SI, en Diccionario Biográfico Español, Real Academia de la Historia, Madrid, 2013, vol. XLVII, pp. 984-988. 
Parecía que el monarca hispano subrayaba la imagen de los jesuitas como cuerpo cuasimilitar que con sus banderas se dirigía a combatir contra la herejía, que era la imagen, precisamente, de la Monarquía católica filipina. En Roma, era mucho más adecuada la orientación del mencionado reformismo vinculado con el Papado, la romanidad frente a una defensa de la ortodoxia protagonizada por el monarca hispano. Es la construcción de la santidad, en este caso «politizada» ${ }^{33}$, defendida desde dos orillas pobladas por sendos monarcas católicos:

La canonizaçión del P. Ignatio de Loyola es tan deseada de la christiandad -escribe Felipe II a Clemente VIII- como se puede hechar de ver por lo que se ha estendido su religión en ella; y por el fructo que haze se conoçe quál fue la planta. Tiénesele muy particular deuoçión en España; y V. Santidad vee quán estendido está su nombre por todo el mundo, y las almas que ganan los suyos aun de entre hereges y infieles; lo qual pareçe que clama ante V. Santidad para que haga esta honrra a quien escogió Dios por instrumento de tanto fructo en su yglesia. Supplico a V. Santidad consuele con esta obra tan digna de su santa mano y de su piedad a todos los buenos cathólicos, pues ha de ser para mayor gloria y seruiçio de Dios nuestro señor, y para confusión de los hereges, que tanta rabia muestran contra este Santo; y a buen agüero puede V. Santidad tener que se la aya guardado Dios para su dichoso tiempo, pues sin duda será una de las grandes memorias y de mucho loor que puede V. Santidad dexar de sí en la yglesia cathólica, con que yo recibiré tan gran merced como lo dirá el duque de Sessa, a quien me remitto Nuestro Señor guarde y prospere la muy santa persona de V. Beatitud, al bueno y felice regimiento de su universal iglesia, como la christiandad lo merece ${ }^{34}$.

Además de estas tensiones en la Curia vaticana, Esther Jiménez subrayaba la importancia de la aproximación de Enrique IV de Francia hacia la Compañía y de ésta al monarca francés. A los padres de la Congregación provincial les expuso Ribadeneyra que el desarrollo de todo este proceso se había visto interrumpido por los «negocios de Francia y Vngría». Se refería precisamente a la necesaria absolución pontificia hacia Enrique IV y la guerra de los turcos contra los húngaros, «tan pesados y dificultosos que cortaron el hilo al nuestro». Había sido el teólogo jesuita Benedetto Giustiniani el que mostró su parecer para que se produjese la anulación del matrimonio entre Enrique IV -Enrique de Navarra- con Margarita de Valois, la hermana de los últimos monarcas franceses. La que habría de ser su

33 JimÉNEZ PABlo, La canonización de Ignacio de Loyola..., op. cit., p. 87.

34 Carta de Felipe II a Clemente VIII, San Lorenzo de El Escorial, 6 de agosto de 1594, en MHSI, Monumenta Ignatiana, t. II, pp. 127-128. 
nueva esposa, María de Medici -la católica hija del duque de Toscana- había sido apoyada en su matrimonio por el papa Clemente. De esta manera, la influencia francesa contrarrestaba la hegemonía de la Monarquía de España en aquellos territorios en los que el papado estaba tan interesado ${ }^{35}$. Sin embargo, a juicio de Ribadeneyra todo fue retomado, en el proceso que nos ocupa, por la intervención del Rey católico y de su embajador, teniendo en cuenta que, al mismo tiempo que se negociaba en Roma, se trataba en España con los mencionados procesos informativos en distintas ciudades.

La que habría de ser la nueva esposa de Enrique IV en 1600, María de Medici, se había convertido en una importante valedora del regreso de los jesuitas a Francia, después de que su esposo los hubiese expulsado, acusados por el Parlamento de París y por la Universidad de la Sorbona de regicidas. Consecuencia de todo ello había sido el intento de asesinato que Jean Châtel -que había estudiado en el colegio Clermont- había perpetrado contra el monarca francés. Consideraban que algunos manuales de teoría política habían sido la mente pensante para esta acción, aunque la obra de Juan de Mariana fue publicada en 1599. Sin embargo, en una nueva relación con Roma, si el rey de Francia era un monarca católico convencido, si París verdaderamente bien valía una misa, con la petición del pontífice, de la reina María y de la carmelita florentina Magdalena de Pazzi -muy influyente en esta última- se podía alcanzar el horizonte del regreso de la Compañía de Jesús, con el edicto de Rouen de 1603, sin olvidar la presencia del confesor jesuita Pierre Coton. El monarca francés ahora era el que perdonaba y los jesuitas se convertían en agentes de recatolización de una antigua nobleza hugonote. $\mathrm{Y}$ además, cuando se estaba produciendo el debate de la controversia de la gracia o «de auxiliis» entre los de la Compañía y los dominicos, la Monarquía francesa apoyaba a los hijos de Ignacio de Loyola. Todo este cambio de actitud en Francia hacia los jesuitas era muy importante en el impulso al proceso de santificación de los futuros santos reformadores. La imagen impulsada de Ignacio de Loyola no se detuvo en él, sino que se prolongó también en la instrumentalización de su compañero Francisco Javier, que había sido también estudiante en París. La reivindicación, a veces, provocaba ciertas «piruetas» y así desde este ámbito político francés se ubicaba el nacimiento, tanto de Ignacio de Loyola como de Francisco Javier, en el reino de Navarra, tan asimilado a la persona de Enrique IV, cuando en realidad las familias de Ignacio y Javier se enfrentaron.

35 JiMÉNEZ PABLO, La canonización de Ignacio de Loyola..., op. cit., p. 92 
Felipe III se pudo mostrar más cercano al modelo de espiritualidad reformista y así solicitó a Clemente VIII, como no olvida Pedro de Ribadeneyra ${ }^{36}$, la subida a los altares del fundador de la Compañía desde esas coordenadas eclesiales. Una Monarquía católica de comportamientos cotidianos levíticos como lo era la reina Margarita de Austria en su presencia habitual en los conventos de las reformas religiosas ${ }^{37}$. Sin embargo, aquel duque de Lerma, su valido, que era nieto del duque de Gandía que había profesado jesuita -Francisco de Borja- no se mostraba tan próximo a la Compañía, a pesar de sus deseos efímeros de abandonar las vanidades del mundo y convertirse en jesuita ${ }^{38}$. De hecho, había recibido desde destacados jesuitas, como el confesor de la Reina Ricardo Haller, notables críti$\operatorname{cas}^{39}$. De nuevo, encontramos un nuevo problema de convivencia entre un jesuita, la Curia romana de la Compañía y el poder político representado por el grupo del duque de Lerma. No es otro que el padre Fernando de Mendoza, calificado como «ingobernable» por uno de sus rectores, Hernando de La Cerda, en el colegio de Medina del Campo. Todo se complicó todavía más mientras fue confesor y hombre de confianza de Fernando Ruiz de Castro, conde de Lemos, y de su esposa Catalina de Zúñiga, hermana del duque de Lerma. Aquaviva mostró mucha paciencia en todo el proceso y conoció muy pronto que Mendoza era protegido por Clemente VIII, el cual impidió que tanto en Nápoles (los Lemos eran virreyes) como en la corte vallisoletana de Felipe III cualquier medida de reforma y some-

36 PEDRo De RIBADENEYRA, Relación de lo que ha sucedido en el negocio de la Canonización del bienaventurado P. Ignacio de Loyola, fundador de la Religión de la Compañía de Jesús y de lo que acerca de su beatificación ba hecho la Santidad de nuestro señor Paulo Papa V, este año de 1609, Madrid, 1609: «El rey [Felipe II] mi señor, que haya gloria, supllicó a V. Santidad (y yo también lo he hecho) por la canonización del B. Ignacio de Loyola con harto desseo de ver el efecto; y como hasta agora no le ha tenido, bueluo de nueuo a suplicar a vuestra beatitud sea servido de no differir más esta honrra a este B. varón, y que ordene que se tome información de su vida y milagros, pues agora biven muchas personas graves que pueden hazer buen testimonio, y se van acabando apriessa. Assegurando a vuestra beatitud que por muchas razones del servicio y gloria de Dios recebiré en esto muy particular gracia y favor de vuestra santidad, como lo dirá más particularmente el duque de Sessa, del mi consejo de estado, y mi embaxador, a quien me remitto. Nuestro Señor guarde y prospere la muy sancta persona de vuestra santidad al buen y felice regimiento de su universal yglesia, como la xpiandad, lo ha menester», Carta de Felipe III al papa Clemente VIII, Lerma 3 mayo 1601, en MHSI, Monumenta Ignatiana, p. 498.

37 Luis Enrique RodrígueZ-SAN PEDro BeZARes, La dualidad de Teresa de fesús y el proyecto de «jesuitas descalzos», en Hispania Sacra, 68/137 (2016), pp. 299-315, ha relacionado este ámbito de espiritualidad entre jesuitas y carmelitas.

38 Francisco de CereCEDA, La vocación jesuítica del Duque de Lerma, en Razón y Fe, 605 (1948), pp. 512-523.

39 Julián J. Lozano NaVArro, La Compañia de fesús y el poder en la España de los Austrias, Cátedra, Madrid, 2005, pp. 119-147. 
timiento de este confesor jesuita fuese posible. La venganza que urdió Mendoza contra Aquaviva fue plenamente apoyada por el Papa. Pretendía que el prepósito general visitase España para asegurar el buen gobierno sobre los jesuitas. Era una vuelta a los argumentos antiguos de los memorialistas ${ }^{40}$. Por el contrario, el nuevo Enrique IV se mostraba más cercano a la espiritualidad jesuítica, que no ignaciana, a través del confesor real, el mencionado padre Cotton. Se había facilitado, incluso, el envío de misiones contra los otomanos y hacia Canadá.

La beatificación de nuestro B. P. Ignacio se ha celebrado en estos reynos con aplauso y regozijo tan uniuersal -escribe Aquaviva a los provinciales de España-, según de diversas partes nos han escrito, que por ello quedamos muy obligados a dar al Señor las debidas gracias, y ha supplicarle que se sirua despertar los ánimos de los de la Compañía con nueuos feruores para caminar en el camino de la perfección según nuestro instituto pide.

Y para que en la commún alegría del pueblo se hechase de ver nuestra modestia, jusgamos ser conueniente aduertir a V. R. que el día del tránsito de nuestro B. P. no se haga desmostración de fiesta extraordinaria en nuestras iglesias [se refería al 31 de julio de 1610], contentándose los nuestros con decir su missa, según la facultad que para ello nos concedió su sanctidad en el breue que ya tenemos imbiado a V. R.; a quien ha parecido preuenir tanto tiempo antes, para que le tenga de abisar a los superiores inmediatos, y encargarles la puntualidad de sancta obediencia deste orden, abisándolos después, de lo que en ello se hubiere hecho ${ }^{41}$.

Con esta occasión no dejaré de decir que así como el aber sido accepta la beatificación y el aberse celebrado de los de fuera con tantas demonstraciones de contento y regocijo, creemos que ha ayudado para abreviar lo de la canonización, por el contrario se puede temer que excediendo agora los nuestros en lo dicho, podría ser occasión de differilla, con harta pena y desconsuelo de todos ${ }^{42}$.

40 Paulo V, Papa desde 1605 (tras el breve pontificado de dieciseis días de León XI), pensaba que el problema se tenía que resolver con la cesión de ambas partes y decidió poner tierra de por medio, o mejor agua, nombrándole en 1607 obispo de Cusco. Las Indias provocaron el cambio de actitud, alejado Fernando de Mendoza de las intrigas de la Corte, que condujo a una reconciliación con la Compañía. Antonio Egaña consideraba que Fernando Mendoza no solamente fue un sujeto indisciplinado como creía Astrain sino un «paranoico inconforme» que se mostraba amargado por la negativa de las dimisorias que pidió en su juventud para salir de la Compañía y que Aquaviva no le concedió. Cfr. Antonio ASTRAIN, Historia de la Compañia de fesús en su Asistencia de España, Madrid, 1909, t. III, pp. 652-677; Antonio DE EGAÑA, Historia de la Iglesia en la América Española, Hemisferio Sur, BAC, Madrid, 1966, pp. 311-312; LOZANO NAVARrO, La Compañía de Jesús..., op. cit., pp. 136-147.

41 Copia de una carta del prepósito general Claudio Aquaviva a los provinciales de España, Roma 11 abril 1610, en MHSI, Monumenta Ignatiana, p. 960.

42 Carta de Alonso Ramírez, en ibid., pp. 960-961. 
Precisamente, un 3 de diciembre de 1609, se firmó el breve decretado de Paulo V por el cual Ignacio de Loyola se convertía en beato ${ }^{43}$. Se empezaron a unir voces para alcanzar el siguiente paso, el definitivo. Comenzó desde un obispo de Estiria, siguió por la provincia de Guipúzcoa ${ }^{44}$, la ciudad de Barcelona o incluso por el embajador de Felipe III en Roma que ya trabajaba por la aceleración de la canonización ${ }^{45}$. Por aquellos mismos días, pedirá lo mismo el rey Segismundo de Polonia. El monarca murió en 1621, el mismo año -el 9 de febrero- en que el cardenal Alessandro Ludovisi, alumno que fue del Colegio Romano, era elegido papa con el nombre de Gregorio XV. Esta promoción de la santidad entró en el ámbito del profetismo, pues se recordó que la presencia de los jesuitas en Francia había coincidido con el nacimiento de un prometido heredero y delfín para esa corona, el futuro Luis XIII, precisamente el mismo día en que Paulo III había aprobado muchos años antes la Compañía de Jesús a través de la bula Regimini Militantis Ecclesiae (27 de septiembre de 1540) ${ }^{46}$. Luis XIII había perdido a su padre Enrique IV, tras su asesinato en 1610 y se encontraba bajo la regencia de su madre.

La que habría de ser la esposa del heredero español, Felipe IV, la reina Isabel de Borbón -hija de Enrique IV y de María de Medici- se presentó desde Madrid como impulsora solícita de este nuevo santo: «los grandes futuros espirituales que la religión de la Compañía ha hecho en toda la cristiandad, y en particular en los estendidos y remotos reynos a esta corona -hablaba de los de la Monarquía de España a pesar de ser francesa- me ponen en obligación ver canonizado a su primer fundador». De gran interés era encomendarle a Ignacio de Loyola el gran

43 Breve beatificationis P. Ignatii, Romae 3 decembris 1609, en ibid., pp. 954-956

44 Ibid., pp. 958-959.

45 «Haviendo entendido que los procesos que V. Santidad ha mandado hazer en estos reynos y en los otros de la xpiandad para la canoniçaçión del Padre Ygnaçio, fundador de la Compañía de Jesús, están ya en Roma, no he podido dejar de suplicar a V. Beatitud, como lo hago con mucho encarecimiento, se sirva de acabar este negoçio con la mayor brevedad que fuere posible, y darle $\tan$ felize fin como le promete el buen principio que lleva; porque por aver sido natural destos reynos y noble, su vida tan notable y la religión que instituyó tan provechossa a toda la xpiandad, y la particular devoçión que yo le tengo, deseo ber acabada cossa de que ha de resultar tanta gloria a Dios, honrra a este bendito Padre, lustre a su religión, y a estos reynos donde nació muy grande regoçijo y alegría; en que yo le reçebiré también por las caussas referidas, y muy particular gracia y favor de V. Santidad de todo el cuidado que en ello mandaré poner. Y assí escribo al marqués de Aytona lo acuerde a V. Beatitud de mi parte. Nuestro Señor guarde la muy santa persona de V. Santidad al bueno y próspero regimiento de su universal yglesia», Carta de Felipe III al papa Paulo V, Madrid 7 marzo 1609, en ibid., p. 943.

46 Carta de Luis XIII de Francia al papa Gregorio XV, París 14 febrero 1621, en ibid., MHSI, pp. 978-979. 
negocio de la sucesión de las coronas: «porque tengo librado el buen suceso de mi alumbramiento en la intercesión del B. P. Ignacio, de quien soy intimamente devota». De esta manera, si la reina Isabel de Borbón quería encontrar en Ignacio de Loyola a su valedor en el parto, también ella desde la tribuna del poder temporal habría de convertirse en su valedora ante las instancias de la tierra. Petición que no se reducía al fundador de la Compañía, sino que se extendía a la madre Teresa de Jesús. Con el tránsito de la Corte, la madre de su esposo, Margarita de Austria, había hecho lo mismo con las más variadas advocaciones marianas de Valladolid, Aranda de Duero o Madrid.

Meses después, el pontífice respondía a Isabel de Borbón, exponiéndole las dificultades que existían para cumplir lo que se le pedía, aunque después todas ellas pudieron desaparecer. En el primer día de diciembre de 1621, Gregorio XV decidió que había llegado la hora de canonizar no solo al fundador sino también al impulsor de las misiones jesuíticas Francisco Javier. Era menester otorgar esta información a la Monarquía de los Reyes Católicos y a la del Rey cristianísimo. Anteriormente, Paulo V se habría comprometido a subir a los altares al beato Isidro, tan vinculado con la Corte de Madrid. Nuevos recelos surgieron no solo por la naturaleza española de los nuevos santos -se unía la madre Teresa de Jesús, empujada también por el embajador español- sino también por la inclusión de Felipe Neri, apóstol de Roma, lo que hizo intervenir a cardenales, superiores carmelitas y al prepósito general de la Compañía Mucio Vitelleschi. Gregorio XV envió todo ello a la Congregación de Ritos. Ya en el comienzo de 1622, las dificultades se habían superado y aceptadas estas decisiones por las Cortes de Madrid y París.

Lo que sucedió aquel 12 de marzo de 1622 en Roma podía ser contemplado como un manifiesto triunfo del catolicismo de la Monarquía de España. Según Esther Jiménez ${ }^{47}$ esta percepción podía resultar simplista porque en realidad, al menos tres de aquellos cuatro españoles que fueron canonizados con el «santo de Roma», Felipe Neri, habían sido transformados en valedores de una línea dominante de actuación de la Iglesia romana. Por eso, Ignacio de Loyola se encuentra tan asociado a la escena y a la frase de la «visión de la Storta», por la que Cristo le asegura que será «propicio en Roma».

47 JimÉneZ PABlo, La canonización de Ignacio de Loyola..., op. cit., pp. 100-102. La canonizzazione dei Santi Ignazio di Loiola, fondatore della Compagnia di Gesu e Francesco Saverio, apostolo dell'Oriente. Ricordo del Terzo Centenario XII marzo MCMXXII, Roma, 1922. 


\section{LOS VEHÍCULOS DE TRANSMISIÓN DE UNA SANTIDAD}

La canonización hubiese sido un hecho aislado, más o menos elitista, si no hubiese existido una serie de recursos de difusión, de propagación cuyo objetivo se encontraba en la consolidación de una devoción, que podría ser muy interesante entre los que impulsaron el proceso -asociándolo a esas coordenadas de las relaciones internacionales entre Monarquías- pero que todavía lo es más en los vehículos de difusión de la misma.

\section{III.1. La creación de una imagen}

Hasta ahora no hemos encontramos una profusión de milagros, que llegarán después porque de ellos estaba necesitado este santo con una nueva publicística y con una nueva imagen. El papa Gregorio XV lo había subido a los altares, pero físicamente lo realizará, por ejemplo en Castilla, el escultor gallego afincado en Valladolid, Gregorio Fernández. La representación iconográfica de los santos se involucró profundamente en el discurso de la Contrarreforma. Lo señala John Elliot ${ }^{48}$ cuando afirma que si los protestantes negaban el sacramento de la penitencia, los católicos lo aproximaban a través de sus santos que se arrepentían, se convertían y lloraban por haber negado a Cristo; si los protestantes no otorgaban importancia a María, algunos sectores del catolicismo se lanzaban apoteósicamente con la bandera de su Concepción Inmaculada, convirtiéndose el pintor o el escultor en un medio para plasmar plásticamente este programa. El discurso estético del barroco contrarreformista no era la belleza renacentista y la proporción sino la de la purificación, la carne golpeada, los ojos del martirio, todo sensualidad porque debía apreciarse en y por los sentidos. Era necesario «mover el ánimo de quien la mira», a la imagen, según resaltaba Francisco de Pacheco, el pintor sevillano, a su discípulo Diego Velázquez. La estética y esa imagen resultante, en estos momentos, poseían un carácter didáctico profundo. La imagen de culto y el púlpito debían complementarse, aunque el mencionado maestro Pacheco pensase que la pintura superaba en efecto a la palabra pues era capaz de llegar sin problemas a la ignorancia. La imitación de los santos era acercarse a Dios, espejos de la semejanza de lo supremo en los hombres. Por eso sus vidas, a través del género hagiográfico, se convertirán en fuentes inequívocas de

48 John H. ElliOT, La Europa dividida (1559-1598), Siglo XXI, Madrid, 1973, p. 154. 
los púlpitos y de las creaciones que hoy consideramos artísticas. Las páginas del Flos sanctorum del jesuita Pedro de Ribadeneyra fueron las más consultadas entre los pintores del Siglo de Oro ${ }^{49}$. Hubo escultores, como el mencionado Gregorio Fernández, que se convirtieron en el manejo de la gubia en creadores de formas plásticas de devociones. Así lo destaca Sánchez Cantón en un texto ya clásico de $1942^{50}$. Cuando Fernández tallaba una imagen de san Ignacio lo hacía como plasmación en madera de una devoción y un culto público. Tipologías que no se limitaban únicamente a los géneros mayores, a la pintura y escultura, sino que partían de la eficacia de grabados y estampas.

De estas últimas, con respecto a Ignacio de Loyola, se pueden hallar tempranos testimonios, incluso anteriores a 1609. Ribadeneyra tuvo que ver en todo ello. Luisa de Carvajal, la mujer que quería ser mártir en Inglaterra, escribía desde Valladolid y en 1602, sobre la «estampa iluminada del padre Ignacio» que le había enviado el padre rector del colegio de Sant'Omer. Así se lo exponía a Magdalena de San Jerónimo, mujer próxima a Isabel Clara Eugenia, gobernadora de los Países Bajos ${ }^{51}$. Después, la popularidad de las canonizaciones de 1622 y la posición alcanzada por la Compañía, inclinaron a los jesuitas a recurrir al más importante de los escultores de Castilla en aquellas décadas.

Probablemente Gregorio Fernández conoció también el retrato que ejecutó Jacopino del Conte. Este pintor florentino lo había realizado basándose en los apuntes tomados ante el cadáver del fundador - «quiero avisar que no tenemos ningún retrato suyo sacado tan al propio, que en todo le parezca»-. Nadie se había atrevido a proponer a Ignacio de Loyola que posara ante un pintor. Sin embargo, el retrato del fundador de la Compañía, cuya copia llegó a España en 1584, no agradaba en demasía a Pedro de Ribadeneyra. Este último, no solo biógrafo, fue artífice de la llegada a Castilla de una mascarilla en cera del fundador, extraída de la original que permaneció en Roma. Ya en su vida había incluido una detallada descripción física del mismo: «fue de estatura mediana, ó por mejor algo pequeña y baxo de cuerpo $»^{52}$. El escultor jesuita, hermano Domingo Beltrán de Otazu realizó entonces un busto que se basaba en esta mascarilla y por las

49 Julián Gallego, Visión y símbolos de la pintura española del siglo de Oro, Cátedra, Madrid, 1984, p. 178. PEDRO DE RIBADENEYRA, Flos Sanctorum y libro de las Vidas de los Santos, t. I: Prólogo al Christiano lector, sin paginar, 1. ${ }^{\mathrm{a}}$ ed. 1599.

50 Francisco Javier SÁNCHEZ CANTÓN, Gregorio Fernández y Francisco de Ribalta, en Archivo Español de Arte, XV (1942), pp. 147-148.

51 Carta de Luisa de Carvajal a Magdalena de San ferónimo, Valladolid, 24 agosto 1602, en Biblioteca de Autores Españoles (BAE), n ${ }^{\circ}$ 179, XI, p. 124.

52 Ribadeneyra, Vida del Padre Ignacio de Loyola..., pp. 259-260. 
orientaciones del mencionado escritor. En esta cabeza de barro se basó el pintor Alonso Sánchez Coello para realizar el retrato que le encargó Ribadeneyra -«el que está más acertado y propio es el que Alonso Sánchez retratador excelente del Rey Católico don Felipe el II sacó en Madrid»-. El original no ha llegado a nosotros, aunque su realización se sitúa en 1585. Estuvo mucho tiempo en la Casa Profesa de Madrid y allí pereció en su incendió en mayo de 1931, en los primeros días de la II República. Tampoco se conocen las copias más inmediatas sino únicamente las más tardías.

Ribadeneyra fue también el impulsor de la realización, en 1597, de una estampa de Ignacio de Loyola por el grabador flamenco Pierre Perret, utilizando el retrato de Sánchez Coello como guía. Desde este modelo salieron las referencias que manejó Gregorio Fernández. Pero existía una notable diferencia entre ambas versiones, la pictórica y la escultórica. Mientras que Sánchez Coello presentaba a un san Ignacio con barba, en la mascarilla tenía el rostro rasurado lo que no quiere decir que careciese de barba y bigote en el momento de su muerte ${ }^{53}$. Más importante es la idea apuntada por Rafael Hornedo: Gregorio Fernández encontró en la mascarilla funeraria mayor inspiración. Jesús Urrea lo confirma, hablando de la nariz pronunciada, la barba mal rasurada y la ausencia de pelo en la cabeza. Y no solamente fue fundamental para la imagen de la Casa Profesa de Valladolid sino también para la del fundador en el colegio de San Luis de Villagarcía ${ }^{54}$, localidad cercana desde Tierra de Campos a la Corte del Pisuerga. Tampoco resultaba extraño que los padres de la Profesa -antiguo colegio de San Antonio, fundado en 1545 por la visita de los padres Araoz y Fabro- hubiesen conseguido una de las mascarillas que se habían vaciado en Madrid sobre la original y que ésta se encontrase en esta casa de la Compañía en 1613. Todas ellas se reducían al rostro y tuvo Gregorio Fernández que completarlas, abombando las sienes y logrando el cráneo completo. El escultor tuvo que animar ese rostro, aportando expresividad al modelo.

La primera de las efigies del fundador de la Compañía debida a la factura de este escultor en Valladolid -centro principal de la escultura- se encontraba relacionada con las fiestas de beatificación del fundador. Ya ofrecía Hornedo la posibilidad de relacionarla con Fernández ${ }^{55}$. Si en las fiestas celebradas en

53 Pedro de Leturia, La mascarilla de San Ignacio, en Archivum Historicum Societatis Iesu, 12 (1943), p. 128.

54 Jesús URREa FERNÁNDEZ, Catálogo de la Exposición de Gregorio Fernández 1576-1636, Fundación Banco Santander Central Hispano, Madrid, 1999.

55 Rafael $M^{a}$ de HoRnedo, Tallas ignacianas de Gregorio Fernández y sus imitadores, en Razón y Fe, 696-697 (1956), p. 306. 
Sevilla ${ }^{56}$, se había encargado al maestro Martínez Montañés la escultura del santo, no resulta extraño que la atribución de Hornedo de esta imagen vestida de la Casa Profesa vallisoletana fuese al escultor gallego establecido en la antigua Corte. Valladolid se unió en noviembre de 1610 a las fiestas que se habían celebrado en otras ciudades. En el presbiterio del templo fue armado un rico tabernáculo, donde encima de una peana dorada se encontraba la imagen del beato, «un Sancto Ignacio muy bien acabado». La imagen era de vestir o se vistió, pues la Relación ofrece descripción de la sotana y el manteo de terciopelo negro, aderezado por joyas de oro y pedrería. Todo ello tenía un valor superior a los ciento cincuenta mil ducados. Las abundantes alhajas que adornaron la imagen del fundador probablemente fueron donadas por las señoras de las familias que constituían las clientelas de la Compañía, en este caso, en Valladolid. Sin embargo, a pesar de la magnanimidad de las joyas, el cronista no podía dejar de apuntar lo bien acabada que se encontraba la escultura ${ }^{57}$.

La imagen de san Ignacio, en el colegio de San Luis de Villagarcía -hacia 1610-1613 según Urrea- sostiene en su mano izquierda el libro de las Constituciones de la Compañía, símbolo de la obediencia que debían profesar los jesuitas. La que fue situada en el retablo de la epístola del templo de la Casa Profesa de Valladolid -posterior Real Iglesia Parroquial de San Miguel y San Julián- fue atribuida a Gregorio Fernández para los años 1613-1614, con un marcado realismo. Su acción como fundador se encuentra identificado con esa mano izquierda que sostenía la maqueta de un templo, mientras que en la otra mano sujeta un IHS flamígero, hacia el cual vuelve su mirada. Sabemos que en estos altares se hicieron reformas con motivo de la canonización por el ensamblador Marcos Garay, afectando a las imágenes solamente en algunas pautas de policromía. Existió cierta discrepancia entre autores para fijar su realización -todos ellos antes de 1622-. Lo que sí se puede afirmar es que se convirtió en modelo para otros encargos, en distintos colegios y tallados por escultores del ámbito fernandino. El colegio de Vergara, por ejemplo -fundado en 1593- albergaba otra de las primeras esculturas de san Ignacio, pues a principios de 1614 los jesuitas de esta casa ya se encontraban con negociaciones con Gregorio Fernández para que tallase la imagen. Se iba a situar en un retablo, debajo de la clásica y mencionada «visión

56 Fernando García GuTiÉRrez, San Ignacio de Loyola en la pintura y escultura de Andalucía, en Boletín de Bellas Artes, $\mathrm{n}^{\circ} 19$ (1991), pp. 49-82.

57 Francisco de SOSSA, Relación de las Fiestas, Sermón y oración latina, certamen poético y poesías hechas en esta Ciudad de Valladolid en la solemnidad de la beatificación del Benerable Padre Ignacio de la Compañía de fesús, en veynte y tres de Nouiembre de 1610, Valladolid, 1610. 
de la Storta» como sucedía en la Casa Profesa de Valladolid. Conocemos detalles de su transporte a Vitoria en aquel verano, después de haber sido concluida en el mes de abril. Existe, pues, una unidad de concepción entre todas ellas ${ }^{58}$, atribuyendo al fundador de la Compañía rasgos nobles y señoriales. Es el fundador y reformador de esta Iglesia defendida por Clemente VIII.

\section{III.2. La vivencia festiva de la canonización}

Era necesario otorgar a las canonizaciones un significado, una repercusión, no solo en ambientes más o menos intelectuales, a través de hagiografías o sermones sino con las fiestas y las siempre rentables devociones. El primer lugar donde repercutía una canonización era en Roma. Desde ese momento, las narraciones festivas eran convenientemente recogidas y divulgadas en Relaciones y eran contextualizadas también con la «inflación milagrera del siglo XVII», según el estudio de Rafael Carrasco ${ }^{59}$ y dentro del barroco. Pocos elementos son más barrocos que la fiesta a través del arte efímero, con su intencionalidad política incluida ${ }^{60}$. La fiesta, para su extensión o primero para su desarrollo, necesitaba un escenario que ese arte efímero se esforzaba en crear. En las canonizaciones y beatificaciones también se producía cierta centralización festiva. Cuando en 1610 fue beatificado el fundador Ignacio de Loyola, el primero en celebrarlo fue el colegio de la Corte de Madrid ${ }^{61}$. A la misa pontifical celebrada por el nuncio, asistieron Felipe III y Margarita de Austria - «con su piedad y buen exemplo quisieron despertar la deuoción de su Corte»- ${ }^{62}$. A Madrid le siguieron la Casa Profesa de Toledo y

58 HoRnedo, Tallas ignacianas..., op. cit., p. 317.

59 Breue relación de las ceremonias hechas en la canonización de los SS. Isidro Labrador, Ignacio de Loyola, Francisco Xavier, Teresa de Jesús y Phelipe Neri, canonizados por... Gregorio XV en doce días del mes de março año de 1622, por Iuan Rné, Málaga; Breue relación de las ceremonias hechas en la canonización de los santos Isidoro (sic) Labrador, Ignacio de Loyola, Francisco Xauier, Teresa de Jesús y Filipe Neri: canonizados por... Gregorio XV, en doze días de março año de 1622, por Iuan Chrysostomo Garriz, Valencia, 1622; Miguel de LEÓN, Fiestas de Madrid, celebradas a XIX Iunio de 1622 años en la canonización de San Isidro, San Ignacio, San Francisco Xauier, San Felipe Neri... y Santa Teresa de Jesús, 1622?

60 Cristina OSSWALD, Aspectos de autoridad y poder en las ceremonias de canonización de Ignacio de Loyola y Francisco Favier en Portugal, en Hipogrifo, 1/1 (2013), pp. 43-55.

61 Biblioteca Real Academia de la Historia, Relación de la fiesta de N. Sancto Padre Ignacio que en Madrid se bizo de su [beatificación] a 15 de noviembre de 1609.

62 Alonso de SAlazar, Fiestas que hizo el insigne Collegio de la Compañia de Iesús de Salamanca a la Beatificación del glorioso Patriarcha San Ignacio de Loyola, con los sermones y poesías que uuo en alabança del Santo, por la viuda de Artus Taberniel, Salamanca, 1610, pp. 1-2. 
otros destacados colegios de las cuatro provincias jesuíticas de España ${ }^{63}$. Todas las ciudades, y así lo exponían en las Relaciones, tenían sobradas razones para convertirse en plaza de todas las celebraciones. Gastos que debían ser justificados a través de los méritos ¿Cómo iba a olvidar la ciudad del Tormes, por ejemplo, que Ignacio de Loyola había sido estudiante en la Universidad de Salamanca, aunque no hubiese hecho nada más que entrar y salir porque las sospechas de iluminismo le perseguían de un lugar a otro?

Las celebraciones litúrgicas casi siempre se encontraban presididas por los notables de la ciudad. El prepósito general Mucio Vitelleschi había hecho una llamada a la modestia con motivo de la celebración de las canonizaciones de los fundadores jesuitas ${ }^{64}$. Fue en Gerona donde al mismo tiempo que se convocó un certamen poético en honor a los nuevos santos también se recordaba la beatificación de $\ll$ S. Luis Gonzaga». En el caso de Valladolid, se organizó una gran procesión general, descrita por el Libro del Secreto del Cabildo Catedral -las páginas donde se reflejaban los acuerdos que iban tomando los canónigos de la Iglesia Mayor-. Solicitaba el superior de la Compañía de Jesús en la ciudad -de la casa que se llamaría de San Ignacio, anterior y mencionada Profesa- que los jesuitas participasen en la misma con sobrepellices, licencia que tenía que otorgar el cabildo. Las sobrepellices son una vestidura de lienzo blanco y fino, con mangas anchas, que se ponen los eclesiásticos sobre la sotana. Acudirían con las otras órdenes religiosas, «en el lugar que les toca por la antigüedad de su religión». Todos estos preparativos se desarrollaron en junio de 1622, aunque la procesión se fijó para el 24 de julio. Días después, los canónigos designaban al jesuita Francisco Pimentel como predicador oficial del sermón. Todo se encontraba reglamentado en aquella procesión, hasta quien habría de llevar las borlas del estandarte de los santos ${ }^{65}$. El recorrido de este cortejo iba a ser muy prolongado,

63 Biblioteca Real Academia de la Historia: Relación de la fiesta que bizo el collegio de Murcia a la beatificaçión del BP. Ignacio de Loyola en 16 de diciembre 1609; Relación de la fiesta que se hizo en esta casa professa de la Compañía de Jesús de la ciudad de Toledo por la beatificación de nro. Bienauenturado P. Sant Ignacio, a 26 Nouiembre de 1609; Relación de una máscara que entre otras fiestas se bizo en Segouia a la beatificación de N.S. Padre; Relación sucinta del admirable ornato que en la fiesta de la Beatificación el Beato Padre Ignacio de Loyola, fundador de la insigne religión de la Compañía de Jesús, se vio en el templo, claustros y patio de la casa de Professos de Sevilla, desde sábado seys de Febrero, hasta Miércoles en la noche, diez del mismo, año 1610.

64 Carta de Mucio Vitelleschi, prepósito general de la Compañía de fesús a los provinciales de Italia, Roma, 9? marzo 1622, en MHSI, Monumenta Ignatiana, pp. 980-982.

65 Archivo General Diocesano Valladolid, Archivo Catedral, Libro del Secreto, 1613-1630, ff. 269v270: «Y ansimesmo se acordó que los cinco santos bayan dentro del Cavildo y clero empezando de esta suerte junto a la Cruz de la Santa Yglesia ha de ir el santo Filipo Neri con su estandarte y 
recalando en una de esas citadas casas de los jesuitas de la ciudad y en el propio convento fundado por la madre Teresa en 1569. El cortejo partía naturalmente de la Catedral -en permanente construcción-. Finalmente, se optó por las calles que recorría la procesión del Corpus Christi. Las imágenes de los cinco santos, junto con su estandarte, debían ir con el Cabildo, el último de ellos «San Isidro de Madrid». Trataron los canónigos de poner en un sitio el protagonismo de frailes y jesuitas, siendo la Catedral el primer templo donde fuesen celebrados los nuevos santos. Cada uno pedía sus singularidades, pero tenían que atenerse a lo dicho por los canónigos, si no querían problemas de competencia y amargarse esta gran fiesta de la santidad. Sin embargo, había otros poderes a los cuales consultar como el municipal, el académico -allí donde hubiese Universidad- o el judicial -si la ciudad era sede de un tribunal de prestigio-. Una vez concluida la procesión, el cabildo catedralicio no podía consentir que las religiones -jesuitas y carmelitas en el caso de Valladolid- hiciesen una procesión por su cuenta, pudiendo contravenir después algunas normativas litúrgicas.

Esta solemnidad era un recurso de atracción para que las gentes se acercasen hasta los respectivos templos de la Compañía, sin olvidar la contemplación de las luminarias que tampoco podían faltar en cualquier fiesta. El lugar para estos espectáculos eran las torres, las fachadas y partes más lucidas hacia la calle. Se convertían en un elemento más de rivalidad entre las diferentes instituciones como había sucedido en los altares efímeros callejeros en la procesión general. Incluso en Salamanca, en 1610, en las fiestas propias de la beatificación, para hacerse cargo de los fuegos, se contó con un chino - «hombre raro y singularíssimo en noticia de fuego y de esquisitas inuenciones, el qual esta noche con una breue muestra dexó admirada la Ciudad»- ${ }^{66}$.

Tampoco faltaba el espacio para las letras, sabiendo por ejemplo que el teatro poseía una gran importancia en la pedagogía de la Compañía ${ }^{67}$. De nuevo en las fiestas de beatificación de Ignacio de Loyola y en Salamanca, un clérigo de la

en segundo lugar más atrás la santa Madre Teresa de Jesús, en tercero el santo Francisco Xabier, en quarto lugar san Ignacio, en quinto y último en el mismo cuerpo del Cavildo san Isidro llevando delante de cada santo con su estandarte, con los quales no ha de ir ningún acompañamiento más que tan solamente el que lleua el estandarte y dos que llevan las borlas».

66 SALAZAR, Fiestas que bizo..., op. cit., p. 22. Cristo José DE LEÓn PERERA, La Compañia de fesús en la Salamanca universitaria (1548-1767). Aspectos institucionales, socioeconómicos y culturales, Universidad Salamanca, Universidad Pontificia, Salamanca, 2020.

67 Matheo FERnÁNDEZ NAVARro, Floresta espiritual con vn Auto sacramental nueuo compuesto por..., tiene al fin del libro la Iusta literaria... a la beatificación del padre Ignacio, fundador de la Compañia de Iesús, en casa de Thomás de Guzmán, Toledo, 1613. 
Cámara Apostólica del Papa, llamado Octavio Corsini, subvencionó los premios del certamen poético que se convocó dentro de estas celebraciones ${ }^{6}$. Se ponían condiciones ajustadas a los temas, plazos de entrega para poder examinar el tribunal, las composiciones en donde no faltaba el patrocinador, los superiores de la orden religiosa, catedráticos y profesores de la Universidad. Interpretaciones e invenciones, que corrían a cargo de diferentes y variados colectivos, sobre todo en las ciudades universitarias con sus estudiantes - « gente que alcança más de ingenio y gusto que de dineros»-. Frente a la falta de recursos económicos, les sobraban las «invenciones». Fueron especialmente significativas en las fiestas de beatificación de Ignacio de Loyola en Salamanca en 1610, las realizadas por un grupo de sus estudiantes y titulada la máscara del «triunfo de don Quijote de la Mancha». Significativa porque solamente cinco años antes se había editado la primera parte del Quijote. La descripción era pormenorizada y en ella podíamos distinguir distintas escenas de variados capítulos de la vida del «ingenioso Hidalgo» ${ }^{69}$.

Cuando las fiestas concluían, el ambiente de apoteosis se había logrado de acuerdo a las intenciones iniciales y se promovía la publicación de una Relación de las mismas. La esencia de estas realidades era efímera. Las palabras que constituían sus sermones o las notas de las músicas se las llevaba el viento. Los instantes, el tiempo, se encargaba de borrarlos, siendo la memoria frágil. Así para evitar lo efímero que conducía al olvido, era necesario entregar a la imprenta detalladas descripciones de todo lo que había acontecido en las fiestas de la santidad. Por eso, nacieron las Relaciones que continuaban con toda la labor publicística que había conseguido la fiesta. Este género, literariamente, también se convertía en arte efímero, pues conseguían siempre recrear en la imaginación del lector, con una considerable exageración y tono hiperbólico, todo lo que había sucedido. Eso sí, el cronista debía describir hasta los más mínimos detalles, con una minuciosidad inaudita. Pero tampoco éste era un testigo neutral de lo que contemplaba (no solamente porque fuese exagerado como hemos dicho) sino porque interpretaba la fiesta. Siempre pensaban los cronistas, en un tono «hagiográfico», que en nin-

68 SAlazAR, Fiestas que bizo..., op. cit., p. 2: «Para animar los buenos ingenios á que empleasen su caudal en alabanças deste glorioso Santo, con Poesías y varias invenciones, el señor Octauio Corsini, cavallero italiano, clérigo de la Cámara Apostólica de Su Santidad, propuso un cartel o certamen poético, cuya copia se pondrá en su lugar, con las Poesías que en esta ocasión se compusieron, señalando mui merecidos premios á su costa, hasta cantidad de ducientos ducados, si bien su liberalidad venció a su promesa, añadiendo otros muchos premios para Poetas dignos dellos, aunque inferiores á los que los alcançaron por rigor del cartel».

69 SALAZAR, Fiestas que bizo..., op. cit., pp. 23-26. 
guna ciudad de España habían alcanzado tal brillantez como en la que describían y a la que servían: «no pienso que ha llegado ninguna cosa de quantas en esta ocasión se ha hecho en España ${ }^{70}$.

Litúrgicamente, también debía quedar un poso de algunas canonizaciones. Peticiones que se realizaban desde las órdenes religiosas, referidas sobre todo al rezo del oficio para el nuevo santo. Un asunto tan importante para los capitulares de cabildos catedralicios dedicados a esta función. Para san Ignacio lo fijaron en julio de 1631 para el día de su festividad, 31 de julio, rezo de «doble confesor no pontífice». Por esta resolución, el superior de la Casa Profesa fue recibido en una de las reuniones -en este caso del Cabildo de Valladolid- para dar las gracias sobre ello ${ }^{71}$. Después se seguirán escribiendo nuevas Vidas de este nuevo santo como sucedió, por ejemplo, con Juan Eusebio Nieremberg.

\section{REFERENCIAS BIBLIOGRÁFICAS}

Fuentes manuscritas

ARCHIVO GENERAL DIOCESANO VALLADOLID

- Archivo Catedral Valladolid, Libro del Secreto, 1613-1630; 1631-1645.

Fuentes impresas

Acta Sanctorum... Fulii. Tomus Septimus, apud Victorem Palmé Bibliopolam, Pariis et Romae, 1868, pp. 420-605.

Bartolomé de AlCáZAR, Chrono-Historia de la Compañáa de Fesvs en la Provincia de Toledo y elogio de sus varones ilustres, fundadores, bienhechores, fautores e hijos espirituales, escrita por..., por Juan Garcia Infançon, Madrid, 1710.

Breve relacion de las ceremonias hechas en la Canonizacion de los Santos Isidoro Labrador, Ignacio de Loyola, Francisco Xauier, Teresa de Iesus y Filipe Neri, Canonizados por la Santidad de nuestro muy Santo Padre Gregorio Papa XV, en 12 dias del mes de Março, año de 1622. En Madrid por Luis Sánchez.

70 Sossa, Relación de las Fiestas..., op. cit.; Francisco de LuQUE FAJARDOS, Relación de la fiesta que se bizo en Sevilla a la beatificación del glorioso San Ignacio, fundador de la Compañía de Jesús, Luis Estupiñán, Sevilla, 1610; Relación de la fiesta que en la beatificación del B.P. Ignacio, fundador de la Compañía de Iesús, bizo el Collegio de la Ciudad de Granada en catorze de febrero de 1610, con el sermón que en ella predicó el señor Don Sancho Dávila y Toledo, obispo de Jaén, en casa de Luys Estupiñán, Sevilla, 1610; SALAZAR, Fiestas que bizo..., op. cit.

71 ARCHIVO GENERAL DIOCESANO VALLADOLID, Archivo Catedral Valladolid, Libro del Secreto 1631-1645, cabildo 21 junio 1631, f. 16; cabildo 28 julio 1631, f. 16v. 
Breue relación de las ceremonias hechas en la canonización de los santos Isidoro (sic) Labrador, Ignacio de Loyola, Francisco Xauier, Teresa de Jesús y Filipe Neri: canonizados por... Gregorio XV, en doze días de março año de 1622, por Iuan Chrysostomo Garriz, Valencia, 1622.

Matheo FERnÁNDEZ NAVARRO, Floresta espiritual con vn Auto sacramental nueuo compuesto por..., tiene al fin del libro la Iusta literaria... a la beatificación del padre Ignacio, fundador de la Compañia de Iesús, en casa de Thomás de Guzmán, Toledo, 1613.

SAN IGNACIO DE LOYOLA, Autobiografía y diario espiritual, introducción de Luis Ma Mendizabal, transcripción y notas de Ignacio Iparraguirre, Candido de Dalmases y Manuel Ruiz Jurado, Biblioteca de Autores Cristianos, Madrid, 1992.

SAn IGNACIO DE LOYOLA, Obras completas de... 1, Autobiografía, Diario espiritual, introducciones y comentarios de Victoriano Larrañaga, Editorial Católica, Madrid, 1947.

Miguel de LEÓN, Fiestas de Madrid, celebradas a XIX Iunio de 1622 años en la canonización de San Isidro, San Ignacio, San Francisco Xauier, San Felipe Neri... y Santa Teresa de Jesús, 1622.

Cristóbal López, Vida del P. Pedro de Ribadeneyra, religioso de la Compañia de fesús, escrita por el mismo Padre al modo de las confesiones de Sant Agustín, añadida por su compañero que lo fue treinta y seis años, el H. Cristóbal López, Madrid, 1612.

Francisco de LUQUE FAJARDOS, Relación de la fiesta que se bizo en Sevilla a la beatificación del glorioso San Ignacio, fundador de la Compañía de fesús, Luis Estupiñán, Sevilla, 1610.

Monumenta Ignatiana, ex autographis vel ex antiquioribus exemplis collecta, serie IV, II, Madrid 1918.

Juan Eusebio Nieremberg, Vida del patriarca San Ignacio de Loyola fundador de la Compañia de Fesus. Resumida, y añadida de la Bula, y Relaciones de su Canonizacion, y de otros graves Autores, Zaragoza: En el Hospital Real y General de Nuestra Señora de Gracia, 1631.

Juan Eusebio NiEREMBERG, Firmamento religioso de luzidos astros en algunos claros varones de la Compañía de fesús, Madrid, 1644.

Joanne Alphonso de PoLANCO, Vita Ignatii Loiolae et rerum Societatis Iesu historia, Tomos I-VI (1491-1556), Monumenta Historica Societatis Iesu, Matriti, 1894-1898.

Relación de la fiesta de N. Sancto Padre Ignacio que en Madrid se bizo de su [beatificación] a 15 de Noviembre de 1609.

Relación de la fiesta que en la beatificación del B.P. Ignacio, fundador de la Compañía de Iesús, bizo el Collegio de la Ciudad de Granada en catorze de febrero de 1610, con el sermón que en ella predicó el señor Don Sancho Dávila y Toledo, obispo de Jaén, en casa de Luys Estupiñán, Sevilla, 1610.

Relación de la fiesta que hizo el collegio de Murcia a la beatificaçión del BP. Ignacio de Loyola en 16 de diciembre 1609.

Relación de la fiesta que se hizo en esta casa professa de la Compañía de fesús de la ciudad de Toledo por la beatificación de nro. Bienauenturado P. Sant Ignacio, a 26 Nouiembre de 1609.

Relación de una máscara que entre otras fiestas se bizo en Segouia a la beatificación de N.S. Padre.

Relación sucinta del admirable ornato que en la fiesta de la Beatificación el Beato Padre Ignacio de Loyola, fundador de la insigne religión de la Compañia de fesús, se vio en el templo, claustros y patio de la casa de Professos de Sevilla, desde sábado seys de Febrero, hasta Miércoles en la noche, diez del mismo, año 1610.

PEDRO DE RIBADENEYRA, Vida del P. Ignacio de Loyola, fundador de la religión de la Compañia de Iesús; y de los Padres Maestro Diego Laynez y Francisco de Borja, segundo y tercero Prepósito

\section{0}


«YO TE SERÉ PROPICIO EN ROMA»

General de la misma Compañia, en las quales se contiene su fundación, progresso y aumento basta el año de 1572, por Pedro Madrigal, Madrid, 1594.

PEDRO DE RIBADENEYRA, Relacion de lo que ha sucedido en el negocio de la Canonizacion del bienaventurado P. Ignacio de Loyola, fundador de la Religion de la Compañia de Jesus. Y de lo que acerca de su beatificacion ha becho la Santidad de nuestro señor Paulo Papa V este año de 1609, Madrid, 1609.

PEDRO DE RIBADENEYRa, Obras escogidas del Padre Pedro de Rivadeneira de la Compañía de Jesús con una noticia de su vida y juicio crítico de sus escritos, edición de Vicente de La Fuente, Biblioteca de Autores Españoles (BAE), Madrid, 1868.

ALONSO DE SAlAZAR, Fiestas que bizo el insigne Collegio de la Compañía de Iesús de Salamanca a la Beatificación del glorioso Patriarcha San Ignacio de Loyola, con los sermones y poesías que uио en alabança del Santo, por la viuda de Artus Taberniel, Salamanca, 1610.

FRANCISCO DE SOSSA, Relación de las Fiestas, Sermón y oración latina, certamen poético y poesías bechas en esta Ciudad de Valladolid en la solemnidad de la beatificación del Benerable Padre Ignacio de la Compañía de Jesús, en veynte y tres de Nouiembre de 1610, Valladolid, 1610.

\section{Bibliografía}

ALDEA, Quintín, Ignacio de Loyola en la gran crisis del siglo XVI, Mensajero, Madrid, 1992.

Astrain, Antonio, Historia de la Compañia de Jesús en su Asistencia de España, III, Madrid, 1909.

BurrieZa SÁNCHEZ, Javier, Toledo, Francisco de, SI, en Diccionario Biográfico Español, Real Academia de la Historia, Madrid, 2013, vol. XLVII, pp. 984-988.

CERECEDA, Francisco, En el cuarto centenario del nacimiento del P. Francisco de Toledo, en Estudios Eclesiásticos, 13 (1934), pp. 90-108.

- La vocación jesuitica del Duque de Lerma, en Razón y Fe, 605 (1948), pp. 512-523.

DE EGAÑA, Antonio, Historia de la Iglesia en la América Española, Hemisferio Sur, BAC, Madrid, 1966.

ELlIOT, John H., La Europa dividida (1559-1598), Siglo XXI, Madrid, 1973.

FERnÁNDEZ MARTÍN, Luis, Peripecia histórica de la «autobiografía» ignaciana, en José Luis OrELLA (ed.), El Pueblo Vasco en el Renacimiento (1421-1521). Actas del Simposio celebrado en la Universidad de Deusto (San Sebastián) con motivo del V. Centenario del nacimiento de Ignacio de Loyola (1-5 octubre 1990), Mensajero - Universidad de Deusto, Bilbao, 1991, pp. 161-190.

GallegO, Julián, Visión y símbolos de la pintura española del siglo de Oro, Cátedra, Madrid, 1984.

GARCÍA CÁRCEL, Ricardo, La crisis de la Compañía de fesús en los últimos años del reinado de Felipe II (1585-1598), en La Monarquía de Felipe II a debate, Sociedad Estatal Conmemoraciones, Madrid, 2000, pp. 383-404.

GARCÍA GuTIÉRREZ, Fernando, San Ignacio de Loyola en la pintura y escultura de Andalucía, en Boletín de Bellas Artes, $\mathrm{n}^{\circ} 19$ (1991), pp. 49-82.

GARCÍA HERnáN, Enrique, Ignacio de Loyola, Taurus - Fundación Juan March, Madrid, 2013.

GARCÍA MATEO, Rogelio, Loyola y el luteranismo ¿Contrarreformista o reformista?, en Estudios Eclesiásticos, 82 (2007), pp. 309-338.

GRÉGOIRE, Réginald, Manuale di agilogia. Introduzione alla letteratura agiografica, Monastero San Silvestro Abate, Fabriano, 1996. 
HoRnedo, Rafael $M^{\mathrm{a}}$ de, Tallas ignacianas de Gregorio Fernández y sus imitadores, en Razón y Fe, 696-697 (1956), p. 306.

JimÉNEZ PABLO, Esther, La forja de una identidad. Las Compañia de Jesús (1540-1640), ediciones Polifemo, Madrid, 2014.

- La canonización de Ignacio de Loyola (1622): Lucha de intereses entre Roma, Madrid y París, en Chronica Nova, 42 (2016), pp. 79-102.

LABARGA, Fermín, La recepción de Lutero en España, en Gert MELVILLE y Josep Ignasi SARANYANA ClOSA (eds.), Lutero 500 anni dopo. Una rilettura della Riforma luterana nel suo contesto storico ed ecclesiale, Libreria Editrice Vaticana, Città del Vaticano, 2019, pp. 239-264.

DE LEÓn PERERA, Cristo José, La Compañía de Fesús en la Salamanca universitaria (15481767). Aspectos institucionales, socioeconómicos y culturales, Universidad Salamanca, Universidad Pontificia, Salamanca, 2020.

Leturia, Pedro de, Nuevos datos sobre San Ignacio: la labor de Polanco y Nadal en los orígenes de la biografía ignaciana a la luz de documentos inéditos, Mensajero del Corazón de Jesús, Bilbao, 1925.

LetUria, Pedro de, La mascarilla de San Ignacio, en Archivum Historicum Societatis Iesu, 12 (1943), pp. 119-134.

Lozano Navarro, Julián J., La Compañia de fesús y el poder en la España de los Austrias, Cátedra, Madrid, 2005.

Osswald, Cristina, Aspectos de autoridad y poder en las ceremonias de canonización de Ignacio de Loyola y Francisco Favier en Portugal, en Hipogrifo, 1/1 (2013), pp. 43-55.

Rebollo (coord.), Alejandro, Signa Christi. Símbolos y emblemas de la Pasión, Valladolid, 2015.

RodrígueZ-SAN PEDRo BEZARES, Luis Enrique, La dualidad de Teresa de fesús y el proyecto de «jesuitas descalzos», en Hispania Sacra, 68/137 (2016), pp. 299-315.

SÁNCHEZ CANTÓn, Francisco Javier, Gregorio Fernández y Francisco de Ribalta, en Archivo Español de Arte, XV (1942), pp. 147-150.

SÁNCHEZ DE LAMADRID, Rafael, El tratado del Cardenal Toledo sobre la canonización de los santos, en Archivo Teológico Granadino, 3 (1940), pp. 171-210.

SANTOS HERnÁNDEZ, Ángel, Jesuitas y obispados. La Compañia de fesús y las dignidades eclesiásticas, Universidad Pontificia de Comillas, Madrid, 1998.

Suñer, P., Toledo, Francisco de, SI, en Quintín Aldea, Tomás MarTíneZ y J. Vives GaTell, Diccionario de Historia de la Iglesia española, Instituto Enrique Flórez, CSIC, Madrid 19721987, vol. IV, pp. 2572-2574.

TACCHI-VENTURI, Pietro, Storia della Compagnia di Gesù in Italia narrata col sussidio di fonti inediti dal P..., I, Roma-Milano, 1910.

Tellechea IDÍGORAS, José Ignacio, Ignacio de Loyola, solo y a pie, Sígueme, Salamanca, 1997.

URrea FERnándEZ, Jesús, Catálogo de la Exposición de Gregorio Fernández 1576-1636, Fundación Banco Santander Central Hispano, Madrid, 1999.

VVAA., La canonizzazione dei santi Ignazio di Loiola, fondatore della Compagnia de Gesù, e Francesco Saverio, Apostolo dell'Oriente. Ricordo del terzo centenario. XII marzo MCMXXII, Roma, 1922.

\section{0}

